\title{
Quantitative Proteomic Analysis of the Interaction Between the Endophytic Plant-Growth-Promoting Bacterium Gluconacetobacter diazotrophicus and Sugarcane
}

\author{
Letícia M. S. Lery, ${ }^{1}$ Adriana S. Hemerly, ${ }^{2}$ Eduardo M. Nogueira, ${ }^{2,3}$ Wanda M. A. von Krüger, ${ }^{1}$ and \\ Paulo M. Bisch' \\ ${ }^{1}$ Unidade Multidisciplinar de Genômica, Instituto de Biofísica Carlos Chagas Filho da Universidade Federal do Rio \\ de Janeiro, Brazil; ${ }^{2}$ Laboratório de Biologia Molecular de Plantas, Instituto de Bioquímica Médica da Universidade Federal \\ do Rio de Janeiro, Brazil; ${ }^{3}$ Departamento de Genética e Biologia Molecular, Universidade Federal do Estado do Rio \\ de Janeiro, Brazil
}

Submitted 5 August 2010. Accepted 21 December 2010.

Gluconacetobacter diazotrophicus is a plant-growth-promoting bacterium that colonizes sugarcane. In order to investigate molecular aspects of the $G$. diazotrophicus-sugarcane interaction, we performed a quantitative mass spectrometry-based proteomic analysis by ${ }^{15} \mathrm{~N}$ metabolic labeling of bacteria, root samples, and co-cultures. Overall, more than 400 proteins were analyzed and 78 were differentially expressed between the plant-bacterium interaction model and control cultures. A comparative analysis of the G. diazotrophicus in interaction with two distinct genotypes of sugarcane, SP70-1143 and Chunee, revealed proteins with fundamental roles in cellular recognition. $G$. diazotrophicus presented proteins involved in adaptation to atypical conditions and signaling systems during the interaction with both genotypes. However, SP70-1143 and Chunee, sugarcane genotypes with high and low contribution of biological nitrogen fixation, showed divergent responses in contact with $G$. diazotrophicus. The SP70-1143 genotype overexpressed proteins from signaling cascades and one from a lipid metabolism pathway, whereas Chunee differentially synthesized proteins involved in chromatin remodeling and protein degradation pathways. In addition, we have identified 30 bacterial proteins in the roots of the plant samples; from those, nine were specifically induced by plant signals. This is the first quantitative proteomic analysis of a bacterium-plant interaction, which generated insights into early signaling of the $G$. diazotrophicus-sugarcane interaction.

Plant-bacteria interactions are widely described (de Wit 2007; Hou et al. 2009; Ortiz-Castro et al. 2009; Staskawicz 2009). Both pathogenic and beneficial interactions have been studied and revealed complex mechanisms of recognition and signaling. For example, symbiotic organisms interact intimately with plants and provide them with metabolic advantages (Den Herder and Parniske 2009; Gibson et al. 2008; Masson-Boivin et al. 2009). Therefore, the plant host might be able to recog-

Corresponding author: L. M. S. Lery; E-mail: 1lery@biof.ufrj.br

* The $\boldsymbol{e}$-Xtra logo stands for "electronic extra" and indicates that a supplementary table is published online. nize these organisms and to signal for pathways that allow them to grow nearby or even inside the plant. The best studied example of bacteria-plant symbiosis is the Rhizobium spp.legume interaction (Martinez-Romero 2009). The plant perceives the Rhizobium cells, and various hosts' signaling cascades lead to the proliferation of specific plant cells around the bacterial infection site. These symbiotic bacteria contribute to plant growth while the plant develops a specialized organ, the nodule, which supports bacterial growth (Martinez-Romero 2009; Masson-Boivin et al. 2009).

In contrast to this nodulation system (Crespi and Frugier 2008; Den Herder and Parniske 2009; Markmann and Parniske 2009), there are fewer studies regarding molecular aspects of the interaction between endophytic bacteria and nonleguminous plants (Hardoim et al. 2008; Long et al. 2008; Ryan et al. 2008). In the last decades, new species of nitrogen-fixing bacteria responsible for biological nitrogen fixation (BNF) have been described in sugarcane plants (Cavalcante and Döbereiner 1988; Döbereiner et al. 1993; Dong et al. 1994; Reinhold-Hurek and Hurek 1998).

Gluconacetobacter diazotrophicus is an $\mathrm{N}_{2}$-fixing bacterium found in roots, stems, and leaves of plants such as sugarcane and sweet potato (Bellone et al. 1997; Cavalcante and Döbereiner 1988; Fuentez-Ramirez et al. 1993, 2001; JimenezSalgado et al. 1997; Loganathan et al. 1999; Muthukumarasamy et al. 2002, 2005; Tapia-Hernandez et al. 2000). Its contributions to a beneficial association with the host plants include nitrogen fixation, production of plant-growth-promoting hormones, secretion of bacteriocins, and solubilization of phosphate and zinc compounds (Arencibia et al. 2006; Blanco et al. 2005; Lee et al. 2004; Munoz-Rojas and Caballero-Mellado 2003; Saravanan et al. 2007; Sevilla et al. 2001). Overall, these mechanisms increase root and foliar growth (Munoz-Rojas and Caballero-Mellado 2003). In previous studies, G. diazotrophicus proteins involved in nitrogen metabolism and bacterial adaptation mechanisms have been pointed out (Dos Santos et al. 2009; Lery et al. 2008a and b). However, proteins directly involved in early signaling $(24 \mathrm{~h})$ between bacteria and hosts were not yet described.

On the other hand, the first studies of this interaction analyzed sugarcane mRNAs differentially represented between expressed sequence tag libraries of plantlets inoculated with G. diazotrophicus and control samples. They revealed mo- 
lecular signaling pathways involved in plant growth promotion and in nitrogen metabolism which were activated during the bacterium-host interaction (Nogueira et al. 2001; Vinagre et al. 2006). Additionally, the percentage of the plant nitrogen assimilated by BNF was calculated for distinct sugarcane genotypes. It was shown that each of them presents different contribution of BNF, suggesting that the plant genotype is, to a certain extent, determining the efficiency of bacteria colonization. The commercial sugarcane genotype SP70-1143 (Saccharum hybrid) presents high BNF contribution, indicating an efficient interaction with diazotrophic bacteria (Urquiaga et al. 1992). However, the sugarcane genotype Chunee (Saccharum barberi) does not benefit much from BNF, suggesting that it establishes an inefficient association with the diazotrophic endophytic bacteria (Urquiaga et al. 1992).

Sugarcane crop production is economically important for food and biofuel production. G. diazotrophicus is a bacterium that improves sugarcane growth; therefore, knowledge of the molecules specifically involved in the establishment of an efficient interaction is a promising strategy for biotechnological developments. Therefore, this study aimed to identify both plant and bacterial proteins involved in early bacterium-host interactions. In order to achieve this aim, we designed and conducted a comparative analysis of $G$. diazotrophicus interaction with the sugarcane genotypes SP70-1143 (high BNF contribution) and Chunee (low BNF contribution) through a pioneer quantitative proteomic analysis.

One of the most reliable methods of quantitative proteomic analysis combines metabolic labeling of cells in culture and relative quantification by mass spectrometry (MS) (Becker 2008; Fenselau 2007; Yan and Chen 2005). The accuracy of results obtained with these protocols is mainly due to the possibility of mixing labeled and nonlabeled samples immediately after they are collected. Therefore, all processing steps are identically performed for both samples, avoiding experimental variations from one sample to the other. The main steps in such a protocol comprise the homogeneous incorporation of the isotopes during cell growth, broad protein extraction procedures, efficient protein separation and digestion, high-resolution liquid chromatography (LC) for peptides separation and highaccuracy tandem mass spectrometry (MS/MS) data acquisition (Beynon and Pratt 2005).

Although such advances in molecular techniques have provided the possibility to detect specific low-copy molecules in a tissue sample (Baldo et al. 2010; Hogslund et al. 2009; Moscatiello et al. 2009; Villeth et al. 2009), the analysis of the microorganism-eukaryote host interaction is still challenging, mainly because microorganism molecules are found "diluted" in the vast amount of eukaryote material. In a few specific examples such as nodulating bacteria, it is relatively simple to isolate bacterial cells from the plant components. However, endophytic bacteria are not easily removed as intact cells from plant samples. For this reason, there are few proteomic studies disclosing proteins of microorganisms expressed inside their hosts.

Thus, in this pioneer study, we have optimized the experimental conditions to produce a reliable comparative proteomic workflow for the analysis of a complex system, such as the coculture of $G$. diazotrophicus and sugarcane. This is an original study making use of the metabolic labeling for a differential quantitative proteomic analysis of a bacterium-plant co-culture system. In particular, the main objective was to disclose the molecular events that take place during the interaction of $G$. diazotrophicus with the sugarcane genotypes SP70-1143 and Chunee. It also represents the first description of $G$. diazotrophicus proteins expressed within roots of its host.

\section{RESULTS AND DISCUSSION}

A reliable quantitative proteomic workflow was established for the study of bacteria-plant interactions.

The use of ${ }^{15} \mathrm{~N} /{ }^{14} \mathrm{~N}$ salts has been the most successful approach for metabolic labeling of plants with isotopes thus far (Bindschedler et al. 2008; Hebeler et al. 2008; Huttlin et al. 2007; Oeljeklaus et al. 2009). Such a strategy has also been applied for the study of bacteria and yeast cells (Hendrickson et al. 2006; Palmblad et al. 2007). However, this approach has never been used to analyze a complex system such as the coculture of a bacterium and its host. Thus, to investigate the differential proteome expression of $G$. diazotrophicus co-cultivated in vitro with sugarcane, the available protocols for quantitative proteomic analysis were optimized in this work. We have combined ${ }^{15} \mathrm{~N} /{ }^{14} \mathrm{~N}$ metabolic labeling of proteins, one-dimensional gel electrophoresis (1D-GE), and LC-electrospray ionization quantitative time-of-flight (ESI-Q-TOF) to obtain a relative quantification measurement of protein expression levels. The relative quantification method used in this work, in contraposition to absolute quantification protocols, provides information on the abundance of a determined molecule in one sample relative to its amount in other samples. A reverse-labeling approach was performed in order to avoid bias on isotopic labeling. The outline of the strategy used is summarized in Figure 1.

Following the optimization procedures, an evaluation of each step of the protocol was carried out. For this purpose, the incorporation of ${ }^{15} \mathrm{~N}$ was estimated as an average of the ${ }^{15} \mathrm{~N}$ incorporation rate according to the variations of isotopic envelope distribution of 20 different peptides randomly chosen from each sample. Bacterial and plant cells in ${ }^{15} \mathrm{~N}$ labeled samples counted approximately 25 and $50 \%$ of ${ }^{15} \mathrm{~N}$ incorporation, respectively. These values assure a reliable quantification approach because, at these rates, labeled and nonlabeled isotopic envelopes are clearly dissimilar (Huttlin et al. 2007). In addition, such low incorporation levels were achieved in a few weeks for plants and a few hours of bacteria growth, allowing less manipulation of the samples. Furthermore, the partial incorporation rates were accounted as correction factors for quantification calculi (Palmblad et al. 2007).

Moreover, for efficient protein extraction, a simple and fast method was employed to guarantee minimal protein loss and degradation. Bacterial and root samples presented several well-resolved protein bands on 1D sodium dodecyl sulfate polyacrylamide gel electrophoresis (SDS-PAGE) $12.5 \%$ bisacrylamide gels. Most of proteins showed molecular weights ranging from 10 to $100 \mathrm{kDa}$. The peptides obtained after the tryptic digestion of proteins spread over the 60-min range of the LC separation on a C18 column, eluted in a linear gradient of 10 to $90 \%$ of acetonitrile. Such high resolution of the chromatographic peaks in LC is a prerequisite for a consistent relative quantification. Comparisons between peak intensities from different peptides in a simple MS spectrum do not reveal any quantitative information, because peptides with different amino acid sequences present different ionization properties. However, the ${ }^{15} \mathrm{~N}$ labeling of a peptide does not modify its ionization properties: it only shifts its mass. Therefore, the quantification method using ${ }^{15} \mathrm{~N}$ labeling is based on a shift of mass of the ${ }^{15} \mathrm{~N}$-labeled peptide relative to the nonlabeled $\left({ }^{14} \mathrm{~N}\right)$ peptide of same sequence. Under this condition, the peak intensity of a ${ }^{15} \mathrm{~N}$-labeled peptide can be compared with the intensity of the ${ }^{14} \mathrm{~N}$ peptide, revealing their abundances in the original samples (Ong and Mann 2005).

A very interesting feature of this methodology is that each peptide can be detected in several MS spectra during the elu- 
tion from the LC column. Because the quantitative measurement depends exclusively on the MS (and not MS/MS) data, it is possible to plot the intensities of the heavy and light peptide for each MS scan of the survey run along the chromatographic peak. The gradient of a linear least square fit of this plot represents the best estimate ratio of ${ }^{15} \mathrm{~N} /{ }^{14} \mathrm{~N}$ (Beynon and Pratt 2005). This approach is so robust that small variations in peptide abundance might be detected with high confidence. A further issue considered was the standard deviation between ratios calculated for different peptides belonging to the same protein. Obviously, those with high deviations among the measurements for the same protein represent an unreliable value and were not considered further.

Finally, the reverse-labeling approach provided an additional aspect of trustworthiness, because it verified approximately $90 \%$ of correspondence between experiment $\mathrm{I}\left({ }^{15} \mathrm{~N} /{ }^{14} \mathrm{~N}\right)$ and experiment II $\left({ }^{14} \mathrm{~N} /{ }^{15} \mathrm{~N}\right)$.

\section{G. diazotrophicus upregulates expression of proteins} involved in general metabolism, adaptation, and signaling during the interaction with distinct sugarcane genotypes.

In order to identify proteins involved in the G. diazotrophicus-sugarcane interaction, we compared the protein expression profile of $G$. diazotrophicus control samples with those of $G$. diazotrophicus co-cultivated with genotypes that exhibit contrasting BNF efficiencies: SP70-1143 and Chunee. Because the co-cultivation system implies that the bacterial cells are under plant signaling stimuli and SP70-1143 presents a high contribution of $\mathrm{BNF}$, this comparison possibly reveals bacterial proteins important for the establishment of an efficient interaction.

Overall, these samples allowed the identification of 278 different bacterial proteins. The quantitative analysis, including replicate verification and reverse labeling, revealed significant differential expression of 34 proteins (approximately $12 \%$ of

A

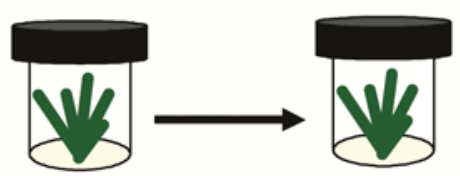

Rooting
Starvation, Adaptation

B
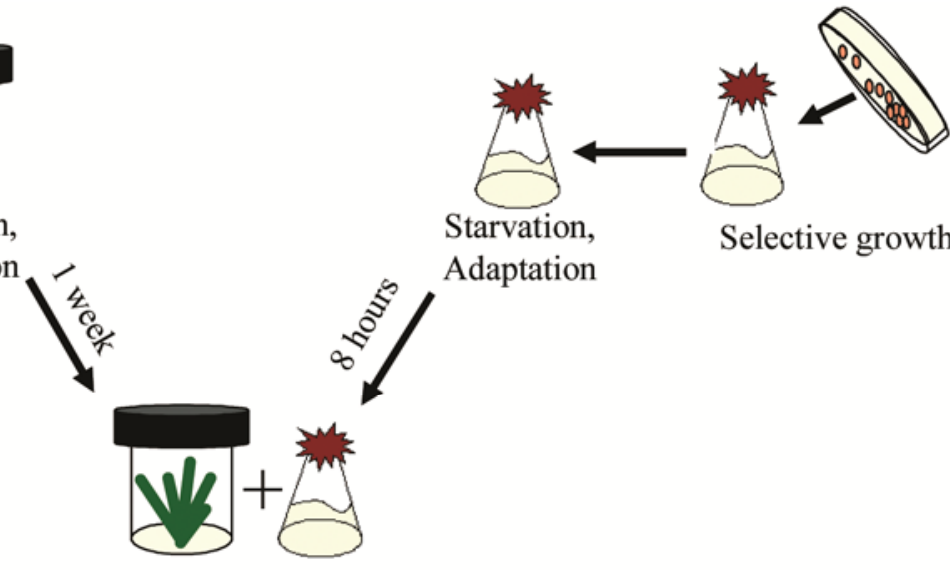

Starvation, Adaptation

Selective growth

Interaction

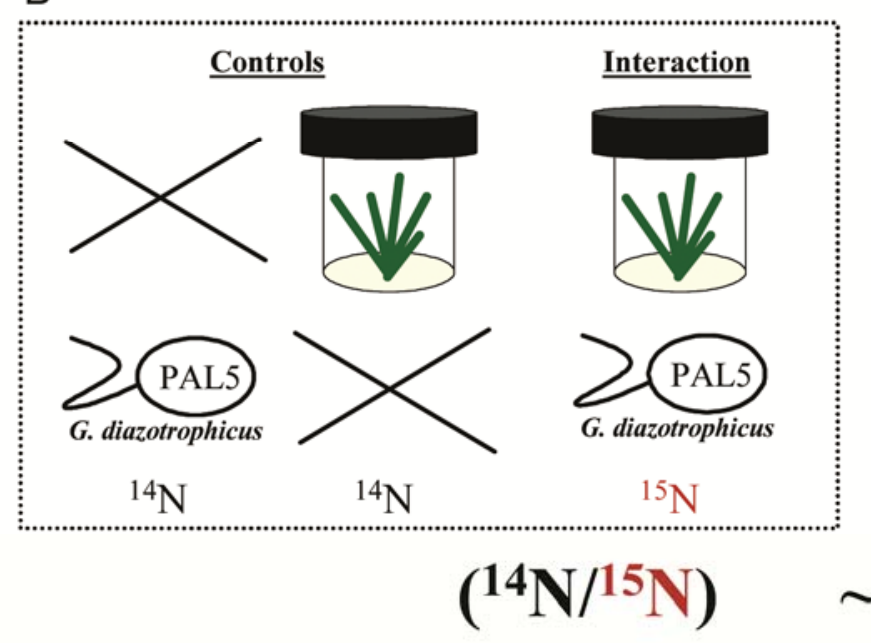

C Stable isotopic
labeling of cells

Protein extraction

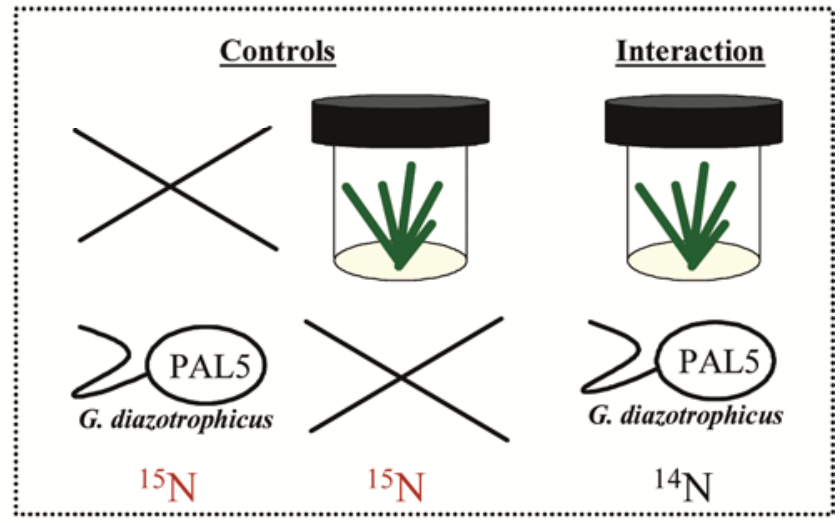

$(15 \mathrm{~N} / 14 \mathrm{~N})$

In gel digestion
MS/MS acquisition

(ESI-Q-Tof)

\begin{tabular}{lcccc}
\hline in vitro culture & Combine & SDS-PAGE & nanoLC peptides & Identification and \\
$(n=6) \times 2 \times 2$ & samples 2 to 2 & separation & separation & quantification
\end{tabular}

Fig. 1. Schematic representation of the methodology followed in this study. A, Bacterium and plant were initially grown in multiplication media and then starved in a 10 -fold diluted MS medium $\left(0.75 \mathrm{mM} \mathrm{MgSO}_{4}, 0.65 \mathrm{mM} \mathrm{KH}_{2} \mathrm{PO}_{4}, 1.5 \mathrm{mM} \mathrm{CaCl}_{2}, 0.05 \mathrm{mM} \mathrm{CoCl}_{2} \cdot 6 \mathrm{H}_{2} \mathrm{O}, 0.16 \mathrm{mM} \mathrm{CuSO} \mathrm{m}_{4} \cdot 5 \mathrm{H}_{2} \mathrm{O}, 45 \mathrm{mM}\right.$ FeNaEDTA, $23 \mathrm{mM} \mathrm{H}_{3} \mathrm{BO}_{3}, 2.5 \mathrm{mM} \mathrm{KI}, 50 \mathrm{mM} \mathrm{MnSO}{ }_{4} \cdot \mathrm{H}_{2} \mathrm{O}, 0.26 \mathrm{mM} \mathrm{Na} \mathrm{MoO}_{4} \cdot 2 \mathrm{H}_{2} \mathrm{O}, 0.36 \mathrm{mM} \mathrm{ZnSO}_{4} \cdot 7 \mathrm{H}_{2} \mathrm{O}, 4.6 \mathrm{mM} \mathrm{MnCl} \cdot 4 \mathrm{H}_{2} \mathrm{O}, 0.05 \mathrm{mM}$ $\mathrm{NH}_{4} \mathrm{NO}_{3}, 2 \mathrm{mM} \mathrm{KNO} 3$, and sucrose at $2 \mathrm{~g} /$ liter) before inoculation with bacteria. $\mathbf{B}$, Control and inoculated samples were grown in minimal media containing ${ }^{14} \mathrm{~N}$ (nonlabeled samples) or ${ }^{15} \mathrm{~N}$ (labeled samples) for the metabolic incorporation of these isotopes in proteins. The reverse labeling strategy was used in order to increase the reliability of the results. C, Protocol steps followed for a reliable measurement of protein expression. 
the identified proteins). Of these, 32 were significantly upregulated and 2 were downregulated during interaction with sugarcane SP70-1143. The proteins and the putative functions assigned to them are summarized in Table 1. Regarding the general functions of proteins more abundant in G. diazotrophicus cells in contact with sugarcane SP70-1143, three main groups of differentially expressed proteins were found: those involved in metabolism, adaptation mechanisms, and signaling systems.

In a second experiment, the protein expression profile of a G. diazotrophicus control sample was compared with that of $G$. diazotrophicus co-cultivated with Chunee sugarcane, which exhibits low contribution of BNF.

In this analysis, $264 \mathrm{G}$. diazotrophicus proteins were identified, of which $43(16 \%)$ were differentially expressed between control and test samples (42 upregulated and 1 downregulated during plant-bacterium interaction) (Table 2). As observed in the interaction with SP70-1143, many G. diazotrophicus proteins were upregulated during interaction and fit into three major groups of proteins: metabolism related, involved in cellular adaptation, and signaling mechanisms.

Of the 32 proteins upregulated by $G$. diazotrophicus during interaction with sugarcane SP70-1143, 20 were also differentially expressed by bacterial cells in the presence of the genotype Chunee (Fig. 2A). This result suggests that G. diazotrophicus presents similar mechanisms of interaction with both sugarcane genotypes. In order to further explore the similarities and differences observed, proteins were grouped according to Kegg categories (Fig. 2B) and the percentage of proteins per category was compared between the G. diazotrophicus-SP701143 and G. diazotrophicus -Chunee interactions.

Similar protein expression profiles were obtained for $G$. diazotrophicus in response to genotypes SP70-1143 and Chunee (Fig. 2). Bacterial cells from both cocultivation systems presented increased expression of proteins involved in metabolism and signaling-pathways, which might have helped them to adapt and survive in the new environment. Such strategy is known to occur during the interaction of Rhizobium spp. with their hosts and might also be part of $G$. diazotrophicus general response to the interaction with sugarcane (Dos Santos et al. 2009; Gibson et al. 2008). Our results suggest that G. diazotrophicus perceives and responds to both sugarcane genotypes through similar general mechanisms.

\section{G. diazotrophicus proteins differentially expressed during interaction with sugarcane SP70-1143.}

The identification of several metabolism-related proteins, including the cell division process and pentose phosphate pathway, indicate that $G$. diazotrophicus cells were active and replicating. They also include proteins involved in carbohydrate metabolism (such as aconitate hydratase, fructose-1,6-bisphos-

Table 1. Proteins differentially expressed by Gluconacetobacter diazotrophicus cells co-cultivated with sugarcane SP70-1143 ${ }^{\mathrm{a}}$

\begin{tabular}{|c|c|c|c|c|c|c|c|}
\hline Accession no. ${ }^{b}$ & Locus & Protein name & MW & Pid score & PM & $\mathrm{I} / \mathrm{C}$ ratio & Std \\
\hline \multicolumn{8}{|l|}{ Upregulated } \\
\hline 162147150 & GDI1355 & Aconitate hydratase & 97 & 490 & 7 & 1.75 & 1.1 \\
\hline 162146316 & GDI0491 & Fructose-1,6-bisphosphate aldolase & 33 & 265 & 2 & 1.32 & 1.0 \\
\hline 162147711 & GDI1927 & Enolase protein & 45 & 126 & 5 & 1.70 & 1.1 \\
\hline 162147402 & GDI1617 & Putative phosphoketolase & 90 & 114 & 9 & 1.96 & 1.1 \\
\hline 162146116 & GDI0286 & Bifunctional transaldolase/phosoglucose isomerase & 102 & 1,238 & 46 & 1.66 & 1.4 \\
\hline 162146115 & GD10285 & Transketolase & 83 & 489 & 11 & 1.43 & 1.1 \\
\hline 162148355 & GDI2572 & $\begin{array}{l}\text { 5-Methyltetrahydropteroyltriglutamate-homocysteine } \\
\text { methyltransferase MetE }\end{array}$ & 85 & 236 & 66 & 2.0 & 1.1 \\
\hline 162146350 & GDI0525 & Glutamine synthetase & 53 & 296 & 18 & 1.81 & 1.2 \\
\hline 162147166 & GDI1371 & Polynucleotide phosphorylase/polyadenylase & 76 & 415 & 11 & 1.61 & 1.0 \\
\hline 162149109 & GDI3339 & Carbamoyl phosphate synthase large subunit & 116 & 358 & 4 & 1.66 & 1.1 \\
\hline 162149180 & GDI3410 & DNA-directed RNA polymerase subunit $\beta$ & 153 & 733 & 36 & 1.51 & 1.1 \\
\hline 162149228 & GDI3460 & $30 \mathrm{~S}$ ribosomal protein $\mathrm{S} 1$ & 62 & 346 & 20 & 1.56 & 1.3 \\
\hline 162146518 & GDI0694 & F0F1 ATP synthase subunit $\alpha$ & 55 & 452 & 10 & 1.69 & 1.0 \\
\hline 162146853 & GDI1036 & ATP-dependent Clp protease proteolytic subunit & 24 & 104 & 2 & 1.32 & 1.0 \\
\hline 162148966 & GDI3196 & Cell division protein FtsZ & 50 & 107 & 8 & 2.22 & 1.1 \\
\hline 209544264 & GDIA2119 & 2-Oxoglutarate dehydrogenase, E2 subunit, & & & & & \\
\hline 162146117 & GDI0287 & dihydrolipoamide succinyltransferase & 44 & 28 & $\begin{array}{r}5 \\
20\end{array}$ & 2.20 & 1.0 \\
\hline 162147824 & GDI2040 & $\begin{array}{l}\text { 6-Phosphogluconate dehydrogenase-like protein } \\
\text { Alcohol dehydrogenase [acceptor] precursor }\end{array}$ & $\begin{array}{l}35 \\
80\end{array}$ & $\begin{array}{l}129 \\
227\end{array}$ & $\begin{array}{r}20 \\
3\end{array}$ & $\begin{array}{l}1.42 \\
1.75\end{array}$ & $\begin{array}{l}1.1 \\
1.1\end{array}$ \\
\hline 162147075 & GDI1280 & Electron transfer flavoprotein subunit $\alpha$ & 31 & 65 & 6 & 1.41 & 1.3 \\
\hline 162147775 & GDI1991 & Isocitrate dehydrogenase & 36 & 60 & 5 & 1.33 & 1.1 \\
\hline 162146401 & GDI0576 & Peroxiredoxin protein & 20 & 62 & 3 & 1.32 & 1.0 \\
\hline 209545461 & GDIA3348 & Translation elongation factor Ts & 32 & 120 & 3 & 1.22 & 1.0 \\
\hline 162147058 & GDI1263 & Chaperone binding & 29 & 28 & 4 & 1.31 & 1.2 \\
\hline 162147057 & GDI1262 & Chaperone protein DnaK & 67 & 30 & 20 & 1.22 & 1.1 \\
\hline 162147833 & GDI2049 & Chaperonin GroEL & 58 & 33 & 41 & 1.51 & 1.3 \\
\hline 162147969 & GDI2185 & Outer-membrane lipoprotein & 40 & 47 & 22 & 1.47 & 1.2 \\
\hline 162147928 & GDI2144 & Outer-membrane protein & 31 & 108 & 3 & 1.40 & 1.1 \\
\hline 162149477 & GDI3715 & TonB-dependent receptor & 94 & 302 & 9 & 2.33 & 1.2 \\
\hline 162147266 & GDI1471 & TonB-dependent receptor protein & 117 & 53 & 40 & 1.33 & 1.1 \\
\hline 209544645 & GDIA2515 & Hypothetical protein Gdia 2515 & 22 & 49 & 3 & 1.12 & 1.0 \\
\hline 162146599 & GDI0777 & Surface antigen protein & 24 & 34 & 2 & $*$ & - \\
\hline 162147251 & GDI1456 & Two-component response regulator & 25 & 60 & 4 & $*$ & _- \\
\hline 209543371 & GDI3420 & Two component transcriptional regulator & 26 & 50 & 4 & $*$ & _- \\
\hline 162147158 & GDI1363 & Transcription elongation factor NusA & 58 & 100 & 2 & 1.43 & 1.0 \\
\hline \multicolumn{8}{|l|}{ Downregulated } \\
\hline 162149580 & GDI3819 & Phosphate-binding periplasmic protein precursor & 34 & 172 & 2 & 0.83 & 1.0 \\
\hline 162147102 & GDI1307 & 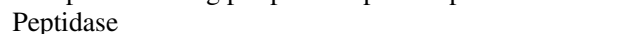 & 80 & 28 & 2 & * & - \\
\hline
\end{tabular}

\footnotetext{
${ }^{a}$ MW, protein theoretical molecular weight; Pid score, mascot protein identification score; PM, number of peptides matched; I/C ratio, relative quantification of protein expression between Interaction and Control samples; Std, standard deviation of the ratio; * indicates protein exclusively expressed in one sample.

${ }^{\mathrm{b}}$ Upregulated or downregulated during bacterium-plant interaction.
} 
phate aldolase, enolase protein, phosphoketolase, bifunctional transaldolase/phosoglucose isomerase, and transketolase), energy metabolism (F0F1 ATP synthase), amino acid metabolism (5-methyltetrahydropteroyltriglutamate-homocysteine methyltransferase [MetE] and glutamine synthetase), nucleotide metabolism (polynucleotide phosphorylase), transcription (DNAdirected RNA polymerase subunit $\beta$ and ribosomal protein $\mathrm{S} 1$ ), and others (ATP-dependent Clp protease and cell division protein FtsZ).

Cellular adaptation occurred during the G. diazotrophicusSP70-1143 interaction. Several proteins differentially expressed further indicate that $G$. diazotrophicus cells sensed plant signals and presented a general response to the interaction in $24 \mathrm{~h}$. Some of these proteins are stress related (chaperone protein DnaK, chaperonin GroEL, translation elongation factor Ts, and chaperone-binding protein) and perform chaperone functions in the cell (Dos Santos et al. 2009; Krab et al. 2001). Proteinfolding assistance is intimately involved in stress response because several stress agents directly interfere with protein folding. Therefore, the increase of chaperone expression levels during cellular adaptation to a stress situation is a necessary process for proper cell functioning under such conditions (Ron 2006). As discussed above, the interaction between an endophytic bacterium and its host is a biotic stress source to both organisms (Baron and Zambryski 1995). Therefore, the identification of these four chaperone-related proteins is coherent with the experiment performed and suggest that, although these bacterial cells did not enter the plant in $24 \mathrm{~h}$, they are already sensing the presence of the sugarcane. Accordingly, increased expression of G. diazotrophicus stress-related proteins were also observed after 7 days of interaction with sugarcane plantlets (Dos Santos et al. 2009), further emphasizing the stressful nature of the co-culture environment to the bacterial cells. PNPase and Clp proteases, products of loci GDI1371 and GDI1036, respectively, also play essential roles in cellular homeostasis during stress in many bacterial species. PNPase of Escherichia coli selectively degrades mRNA for stress-related proteins to avoid overproduction (Yamanaka and Inouye

Table 2. Proteins differentially expressed by Gluconacetobacter diazotrophicus cells co-cultivated with sugarcane Chunee ${ }^{\mathrm{a}}$

\begin{tabular}{|c|c|c|c|c|c|c|c|}
\hline Accession no. ${ }^{b}$ & Locus & Protein name & MW & Pid score & PM & $\mathrm{I} / \mathrm{C}$ ratio & Std \\
\hline \multicolumn{8}{|l|}{ Upregulated } \\
\hline 162146316 & GDI0491 & Fructose-1,6-bisphosphate aldolase & 33 & 348 & 16 & 1.37 & 1.1 \\
\hline 162146116 & GDI0286 & Bifunctional transaldolase/phosoglucose isomerase & 102 & 705 & 66 & 1.32 & 1.1 \\
\hline 162146115 & GD10285 & Transketolase & 83 & 286 & 16 & 1.47 & 1.1 \\
\hline 209543968 & GDIA1822 & Phosphoketolase & 306 & 91 & 6 & 1.35 & 1.2 \\
\hline 162146526 & GDI0702 & Inosine-guanosine kinase & 36 & 36 & 2 & $*$ & - \\
\hline 162147744 & GDI1960 & Phosphoribosylformylglycinamidine synthase II & 77 & 179 & 2 & 1.51 & 1.0 \\
\hline 162147166 & GDI1371 & Polynucleotide phosphorylase/polyadenylase & 76 & 415 & 6 & 1.41 & 1.1 \\
\hline 162147682 & GDI1898 & UTP--glucose-1-phosphate uridylyltransferase & 32 & 194 & 4 & 1.20 & 1.2 \\
\hline 162149109 & GDI3339 & Carbamoyl phosphate synthase large subunit & 116 & 358 & 14 & 1.12 & 1.1 \\
\hline 162146350 & GDI0525 & Glutamine synthetase & 53 & 296 & 6 & 1.51 & 1.1 \\
\hline 162149150 & GDI3380 & DNA-directed RNA polymerase subunit $\alpha$ & 37 & 247 & 11 & 1.33 & 1.2 \\
\hline 162149179 & GDI3409 & DNA-directed RNA polymerase subunit $\beta^{\prime}$ & 155 & 201 & 4 & 1.23 & 1.1 \\
\hline 162149228 & GDI3460 & $30 \mathrm{~S}$ ribosomal protein $\mathrm{S} 1$ & 62 & 346 & 6 & 1.32 & 1.1 \\
\hline 162149173 & GDI3403 & 50S ribosomal protein L4 & 22 & 156 & 3 & 1.69 & 1.1 \\
\hline 162146520 & GDI0696 & F0F1 ATP synthase subunit $\beta$ & 53 & 452 & 7 & 1.32 & 1.0 \\
\hline 162147262 & GDI1467 & Aminopeptidase & 95 & 401 & 6 & 1.45 & 1.3 \\
\hline 162147775 & GDI1991 & Isocitrate dehydrogenase & 36 & 182 & 10 & 1.28 & 1.1 \\
\hline 162146401 & GDI0576 & Peroxiredoxin protein & 20 & 95 & 2 & 1.66 & 1.0 \\
\hline 162149047 & GDI3277 & Putative quinoprotein glucose dehydrogenase & 86 & 83 & 2 & 1.33 & 1.0 \\
\hline 162146117 & GDI0287 & 6-Phosphogluconate dehydrogenase-like protein & 36 & 344 & 28 & 1.32 & 1.1 \\
\hline 162145866 & GDI0024 & Ketol-acid reductoisomerase & 36 & 180 & 9 & 1.45 & 1.0 \\
\hline 162145915 & GDI0079 & Catalase & 55 & 370 & 9 & 1.45 & 1.1 \\
\hline 162147057 & GDI1262 & Chaperone protein DnaK & 67 & 854 & 20 & 1.64 & 1.2 \\
\hline 162147833 & GDI2049 & Chaperonin GroEL & 58 & 394 & 46 & 1.51 & 1.1 \\
\hline 162147665 & GDI1881 & Cold shock-like protein CspE & 23 & 157 & 13 & 1.47 & 1.0 \\
\hline 162148836 & GDI3065 & Elongation factor $\mathrm{G}$ & 77 & 358 & 13 & 1.51 & 1.3 \\
\hline 162148789 & GDI3018 & Elongation factor Ts & 32 & 160 & 3 & 1.56 & 1.1 \\
\hline 162149176 & GDI3406 & Elongation factor $\mathrm{Tu}$ & 43 & 375 & 23 & 1.40 & 1.1 \\
\hline 162147969 & GDI2185 & Outer-membrane lipoprotein & 40 & 382 & 38 & 1.45 & 1.2 \\
\hline 162146629 & GDI0807 & Outer-membrane lipoprotein omp 16 & 16 & 161 & 3 & 1.47 & 1.0 \\
\hline 162147070 & GDI1275 & Outer-membrane protein & 28 & 188 & 6 & 1.72 & 1.1 \\
\hline 162149477 & GDI3715 & TonB-dependent receptor & 94 & 375 & 5 & 1.28 & 1.1 \\
\hline 162147266 & GDI1471 & TonB-dependent receptor protein & 117 & 857 & 21 & 1.59 & 1.2 \\
\hline 162146240 & GDI0415 & Bacteriocin protein & 29 & 49 & 1 & $*$ & - \\
\hline 162146281 & GDI0456 & Chemoreceptor McpA & 57 & 45 & 2 & $*$ & - \\
\hline 162147469 & GDI1685 & Putative chemotaxis protein $\mathrm{Che} A$ & 79 & 38 & 1 & * & _- \\
\hline 162146452 & GDI0628 & Inositol-3-phosphate synthase & 40 & 75 & 3 & $*$ & - \\
\hline 162147515 & GDI1731 & Putative large-conductance mechanosensitive channel & 16 & 30 & 2 & 1.3 & 1.2 \\
\hline 162147529 & GDI1745 & Putative signal transduction histidine kinase & 66 & 35 & 1 & * & - \\
\hline 162147963 & GDI2179 & IclR family transcriptional regulator & 33 & 37 & 2 & $*$ & _ \\
\hline 162148926 & GDI3156 & Transcriptional regulator LysR & 32 & 40 & 2 & * & - \\
\hline 162149456 & GDI3694 & Bacterioferritin & 19 & 32 & 2 & $*$ & - \\
\hline \multicolumn{8}{|l|}{ Downregulated } \\
\hline 162146117 & GDI0287 & 6-Phosphogluconate dehydrogenase & 35 & 344 & 10 & 0.71 & 1.1 \\
\hline \multirow[t]{2}{*}{162148355} & GDI2572 & 5-Methyltetrahydropteroyltriglutamate--homocysteine & & & & & \\
\hline & & methyltransferase MetE & 85 & 160 & 7 & 0.45 & 1.0 \\
\hline
\end{tabular}

\footnotetext{
${ }^{a}$ MW, protein theoretical molecular weight; Pid score, mascot protein identification score; PM, number of peptides matched; I/C ratio, relative quantification of protein expression between Interaction and Control samples; Std, standard deviation of the ratio; * indicates protein exclusively expressed in one sample.

${ }^{\mathrm{b}}$ Upregulated or downregulated during bacterium-plant interaction.
} 
2001). Clp proteases, on the other hand, help bacterial adaptation and survival under stress by degrading misfolded and damaged proteins (Yu and Houry 2007).

Additional mechanisms of cellular adaptation occur during the $G$. diazotrophicus-SP70-1143 interaction. The plasma membrane and lipopolysaccharides function as a protective and selective barrier to bacterial cells. Thus, alterations in these components are regulated according to environmental changes and imply an activation or deactivation of signaling systems (Nikaido 2003). The differential expression of two TonB-dependent receptor proteins, the outer-membrane protein $\mathrm{OmpH}$, and one outer-membrane lipoprotein by $G$. $d i$ azotrophicus in the presence of the plant host suggests that they are part of the bacterial adaptive response to the new environment. Further, the TonB receptors frequently function in cooperation with lipoproteins to control the transport of nutrients to the cell (Veith et al. 2009). Thus, the identification of both a TonB receptor protein and a lipoprotein during $G$. $d i$ azotrophicus interaction with sugarcane reinforces the importance of this mechanism for bacterium-plant signaling. Moreover, TonB-dependent receptors are antigenic proteins involved in iron utilization and virulence in several bacteria (Ferguson and Deisenhofer 2002; Koebnik 2005; Nikaido 2003). Because some TonB peptides are well conserved, it is reasonable that they might represent a pattern for plant recognition of bacterial cells. Additionally, it was described that the TonB homologue of Ralstonia solanacearum, PrhA, binds to the plant host cell wall and initiates a regulatory cascade that induces plant defense responses crucial for plant-bacteria interaction (Brito et al. 2002; Marenda et al. 1998). Therefore, it is reasonable to assume that receptors from the TonB family overrepresented in $G$. diazotrophicus cells during interaction with sugarcane could be involved in sensing plant signals.

The outer-membrane protein $\mathrm{OmpH}$ belongs to a family of immunogenic porins that allows small molecules to flow through the outer membrane but also acts as a receptor or chaperone (Korndorfer et al. 2004; Lee et al. 2007; Missiakas et al. 1996). Thus, its role in $G$. diazotrophicus might be both structural and regulatory.

The general stress response also deals with protecting cellular structures from oxidative damage (Cabiscol et al. 2000; Zuber 2009). Thus, some proteins involved in redox reactions and electron transfer chains are upregulated under stress. During interaction with SP70-1143, G. diazotrophicus specifically superexpressed, for instance, an alcohol dehydrogenase and the 2-oxoglutarate dehydrogenase. Accordingly, an E. coli alcohol dehydrogenase has been shown to constitute the main barrier against oxidative damage (Echave et al. 2003), and aconitase (acn) mutants hypersensitive to the redox-stress reagents produced high amounts of oxoglutarate dehydrogenase. Both enzymes generate $\mathrm{NADH}$, thereby increasing the antioxidant capacity of the cell (Tang et al. 2002). Other regulated proteins that might have similar roles are 6-phosphogluconate dehydrogenase-like protein, electron transfer flavoprotein subunit $\alpha$, isocitrate dehydrogenase, and peroxiredoxin protein. In $E$ coli, a heterologous peroxiredoxin AhpC protected cells against heat, salt, pesticides, metals, and UV-B. stresses (Jacobson et al. 1989). Moreover, in other species, AhpC has been shown to scavenge a variety of peroxides, reactive oxygen nitrogen, and sulfur species (Nguyen-nhu and Knoops 2002). These proteins might be part of the bacterial oxidative stress response demonstrating that $G$. diazotrophicus used mechanisms of protection during interaction with the host. Thus, it suggests that $G$. diazotrophicus is adapted to the interaction with sugarcane SP70-1143.

In addition to the metabolic enzymes and structural proteins, G. diazotrophicus superexpressed proteins with regulatory func- tions during interaction with SP70. Three transcriptional regulators were identified: two two-component transcriptional regulators (GDI3420 and GDI1456) and the transcription elongation factor NusA (GDI1363). The transcription elongation factor NusA is a modulator of RNA polymerase, thus involved in the regulation of gene expression (Nakamura et al. 1986). The two-component transcriptional regulator (GDI3420) identified is $70 \%$ identical to Acetobacter pasteurianum $\mathrm{KdpE}$ protein. In $E$. coli, $\mathrm{KdpE}$ is the transcriptional activator of the $k d p$ FABC operon that codes for an inducible high-affinity potassium uptake system, in response to moderate osmotic pressure in vitro (Altendorf et al. 1994; Jung and Altendorf 2002). It is suggested that the Kdp system is regulated by potassium concentrations and salt stress (Jung and Altendorf 2002). Thus, the increased expression of $\mathrm{KdpE}$ in $G$. diazotrophicus from the co-culture medium might be an indication that the cells, at that stage, were going through the initial phase of the osmoadaptation, which might prepare the cells to adapt to the high osmotic condition within the sugarcane plant. The second twocomponent response regulator identified (GDI1456) belongs to TIGR family 01387 . Most members of this family are part of a system for sensing heavy metals, such as copper, silver, cadmium, and zinc (van der Lelie et al. 1997). Accordingly, G. diazotrophicus is a bacterium that metabolizes insoluble zinc compounds, and it is suggested that the availability of zinc favors G. diazotrophicus host growth (Saravanan et al. 2007).

Two other interesting proteins identified were a hypothetical protein (GDIA2515) and a surface antigen protein (GDI0770). The hypothetical protein GDIA2515 belongs to the YfdX pro-
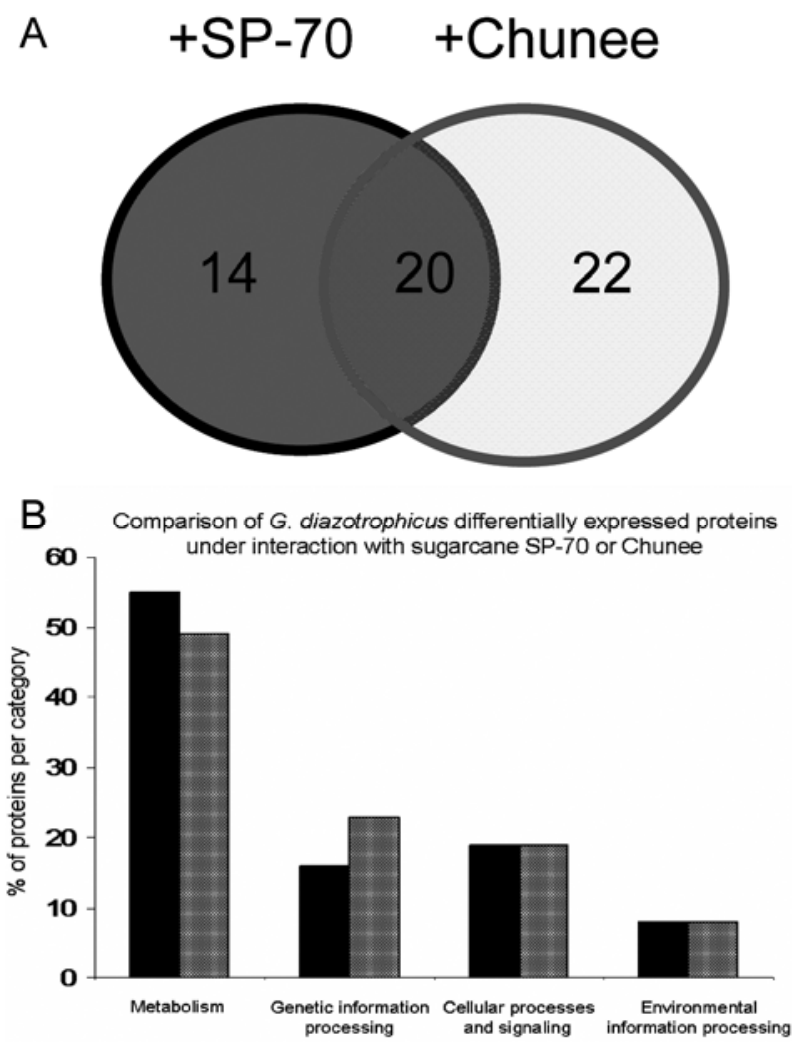

Fig. 2. Comparison of the differentially expressed protein groups in Gluconacetobacter diazotrophicus during interaction with SP70-1143 or Chunee. A, Venn diagram showing the intersection (number of proteins) between the differentially expressed proteins in $G$. diazotrophicus during interaction with SP70-1143 and Chunee. B, Grouping of the differentially expressed proteins according to Kegg categorization. Proteins upregulated during interaction with SP70-1143 are shown in black bars and those increased on interaction with Chunee are in gray. 
tein family of unknown function. This is a very interesting result because hypothetical proteins are usually organism specific. Although annotated as hypothetical, we have confirmed that this protein is really expressed by $G$. diazotrophicus. Likewise, the predicted surface antigen protein does not present high similarity to any other known protein but seems to be part of the early plant-bacteria recognition process.

In contrast with the high number of proteins upregulated during the $G$. diazotrophicus-SP70-1143 interaction, only two proteins were significantly downregulated. They are a phosphate-binding periplasmic protein precursor (GDI3819) and a peptidase (GDI1307).

\section{G. diazotrophicus proteins differentially expressed during interaction with sugarcane Chunee.}

Similar to what was observed with $G$. diazotrophicus co-cultivated with SP70-1143, bacterial cells incubated in the presence of $G$. diazotrophicus on Chunee expressed many metabolism-related proteins relative to the control (Table 2). The 16 metabolic proteins expressed by $G$. diazotrophicus during interaction with Chunee include transcription factors (DNA-directed RNA polymerase subunit $\alpha$ and DNA-directed RNA polymerase subunit $\beta^{\prime}$ ); ribosomal proteins (30S ribosomal protein $\mathrm{S} 1$ and $50 \mathrm{~S}$ ribosomal protein L4); proteins involved in energy metabolism (F0F1 ATP synthase subunit $\beta$ ), carbohydrate metabolism (fructose-1,6-bisphosphate aldolase, bifunctional transaldolase/ phosoglucose isomerase, transketolase and phosphoketolase, and inosine-guanosine kinase), amino acid metabolism (carbamoyl phosphate synthase and glutamine synthetase), nucleotide metabolism (polynucleotide phophorylase, phosphoribosylformylglycinamidine synthase II, and UTP-glucose-1-phosphate uridylyltransferase); and other proteins (aminopeptidase). Many of these proteins were superexpressed in G. diazotrophicus in the presence of both sugarcane genotypes (Tables 1 and 2).

As discussed above, specific responses are required for bacterial cells to adapt and survive under biotic stress. Accordingly, 17 proteins responsive to stress were identified. Among them, six are related to protein folding (chaperone protein DnaK, chaperonin GroEL, cold shock-like protein CspE, elongation factor $\mathrm{G}$, elongation factor $\mathrm{Ts}$, and elongation factor $\mathrm{Tu}$ ), six to oxidative stress (isocitrate dehydrogenase, peroxiredoxin protein, putative quinoprotein glucose dehydrogenase, 6-phosphogluconate dehydrogenase-like protein, ketol-acid reductoisomerase, and catalase), and five to membrane remodeling (outer-membrane lipoprotein GDI2185, outer-membrane lipoprotein Omp16, outer-membrane protein GDI1275, TonBdependent receptor GDI3715, and TonB-dependent receptor protein GDI1471). It is interesting to note that the quinoprotein glucose dehydrogenase is the enzyme that converts glucose to gluconic acid. It was shown that gluconic acid is responsible for solubilization of phosphate and zinc compounds, increasing the availability of these elements for both bacterium and plant nutrition (Intorne et al. 2009). Therefore, the increased expression of this protein during interaction of $G$. $d i$ azotrophicus with sugarcane suggests that this mechanism might somehow be dependent on host environment.

Other interesting protein identifications are related to chemotaxis (McpA and CheA proteins) and inositol metabolism (inositol-3-phosphate synthase). Chemotaxis is the characteristic movement or orientation of an organism along a chemical concentration gradient (Brencic and Winans 2005; Briegel et al. 2009; Hamer et al. 2010). Although a role for chemotaxis in plant colonization by G. diazotrophicus is not yet determined, it is quite suitable that McpA and CheA are key G. diazotrophicus molecules on the communication interplay between $G$. diazotrophicus and sugarcane. If the chemotaxis signal is perceived by the receptor, signaling cascades might be activated and result in bacterial cell movement toward the host (Brencic and Winans 2005). Inositol-3-phosphate synthase is an enzyme involved in the synthesis of inositol, an essential substrate for the biosynthesis of phosphatidylinositol, a minor membrane component in most bacterial membranes. Phospholipids are molecules of bacterial cell envelope and, as such, they are essential for membrane integrity and also for intracellular signaling. In contrast with eukaryotes, in bacteria, the inositol derivatives are not related to signal transduction pathways. They are suggested to function as osmolytes and lipid anchors that are critical for the interaction with host cells (Roberts 2006). Based on that, we hypothesized that the upregulation in $G$. diazotrophicus during an early stage of the interaction with Chunee might be part of a strategy to increase the amount of inositol-containing lipids in the cell envelope. This could improve the ability of $G$. diazotrophicus to deal with the osmolarity of the medium and to interact with the sugarcane plant components.

Similarly to the bacterial cells co-cultivated with SP701143, G. diazotrophicus molecules involved in signaling and regulation of gene expression were identified. The histidine kinase GDI1745 and the transcriptional regulators IciR and LysR might be related to signal transduction and modulation of cellular metabolism, further indicating that bacteria sensed and responded to changes in the environment by activating signaling pathways.

In addition, two other proteins were upregulated during the G. diazotrophicus-Chunee interaction: a bacterioferritin and a bacteriocin protein. The bacterioferritin is a protein involved in iron storage (Carrondo 2003). Further studies are required to determine the overlap between bacterial colonization in plants and iron metabolism. The bacteriocin Gdi0415 is a linocin M18 family member that act as an antimicrobial peptide. In fact, it is already shown that $G$. diazotrophicus antagonizes the growth of some sugarcane pathogens in culture medium (Arencibia et al. 2006; Blanco et al. 2005; Saravanan et al. 2008). However, this is the first report of the expression of a G. diazotrophicus bacteriocin instigated by the presence of the sugarcane host.

Altogether, the identification of these proteins, upregulated during the $G$. diazotrophicus-Chunee interaction, indicates that the bacterial cells sense and respond to the interaction with this low-BNF contribution genotype. On the other hand, one additional protein was downregulated under the same conditions, i.e., MetE. Its expression was increased approximately twofold during interaction with SP70-1143 and decreased twofold during interaction with Chunee (Tables 1 and 2). MetE is a protein involved in methionine metabolism, responsible for the homocysteine conversion in methionine in a cobalamin (vitamin B12)-independent reaction. Such a methionine pathway is part of sulfur metabolism but its role during symbiotic interactions is not yet described. However, it has been shown that the homocysteine-methionine cycle directly influences the production of autoinducer molecule AI-2 (Winzer et al. 2002). AI-2 is known as a quorum-sensing molecule involved in interspecies cell to cell signaling. Thus, the differential expression of MetE might possibly suggest that $G$. diazotrophicus presents a more efficient communication system during interaction with SP70-1143 than with Chunee, leading to a promising interaction with the high-BNF contribution genotype SP70-1143.

\section{Sugarcane genotype SP70-1143 upregulates proteins involved in cellular adaptation and signaling during interaction with $G$. diazotrophicus.}

In order to disclose sugarcane proteins involved in the interaction with $G$. diazotrophicus, we compared the protein expression profiles of SP70-1143 roots that were inoculated with G. diazotrophicus with control samples. 
Overall, 61 sugarcane proteins were confidently identified from SP70-1143 root samples. Although not many proteins were identified, it was possible to quantify their expression and detect seven proteins (approximately 11\%) exclusively expressed by SP70-1143 roots during interaction with $G$. diazotrophicus (Table 3). The differentially expressed proteins were L-ascorbate peroxidase, an ATP citrate lyase, TUA6 protein, glutamate ammonia lyase, 14-3-3 protein, ATP-binding protein kinase, and a receptor like kinase.

The L-ascorbate peroxidase is involved in oxidative stress response, a known protective mechanism required under biotic stress challenges (Shigeoka et al. 2002). Another adaptive mechanism induced in host cells under this condition is related to lipids metabolism. The ATP citrate lyase is a key enzyme for the regulation of lipids biosynthesis, thus indicating that SP701143 changes lipids in the membrane in order to respond to bacterial infection. The modulation of lipid composition is very important for the colonization process of other bacteria and agrees with the altered morphology of plant cells previously observed (Jiao et al. 2008). Additionally, it was demonstrated that cytosolic ATP citrate lyase of sweet potato is involved in protection of plant cells against pathogen infection, thus indicating the involvement of this protein in the response to bacterial interaction (Takeuchi et al. 1981). Hence, TUA6 is a membrane protein whose function is not yet clear but its identification is an additional evidence that the cell membrane is an essential component for bacteria-host interaction.

Some proteins upregulated in SP70-1143 might be involved in signal transduction pathways. It seems to be the case of the 14-3-3 protein, from a highly conserved family of proteins that play important roles in several signaling pathways and present a motif of interaction with several other signaling molecules
(Oecking and Jaspert 2009; Paul et al. 2009). It is upregulated in several plant biotic and abiotic stresses (Roberts et al. 2002). Further studies are required for the correct assignment of its function. Furthermore, increased expression of two protein kinases (a putative tyrosine kinase and a putative receptor like kinase) in SP70-1143, suggests the activation of signaling cascades induced by $G$. diazotrophicus interaction.

Finally, the identification of glutamate ammonia lyase indicates an increased nitrogen metabolism in SP70-1143 plants grown with $G$. diazotrophicus. It is known that $G$. diazotrophicus raises nitrogen inputs for plant growth (Muthukumarasamy et al. 2006).

\section{Sugarcane genotype Chunee upregulates the expression of proteins involved in plant defense mechanisms in response to $G$. diazotrophicus interaction.}

Compared with sugarcane genotype SP70-1143, Chunee root samples inoculated with $G$. diazotrophicus presented a distinct set of upregulated proteins relative to the control sample.

The proteomic analysis of Chunee roots inoculated with $G$. diazotrophicus revealed nine differentially expressed proteins from 82 identified. Among these, there were two distinct subunits of the proteasome complex, three histones, a cell-cycle regulator, an ethylene receptor, and two other membrane proteins (Table 4).

The increased level of proteasome components suggests that protein degradation occurs in infected Chunee roots cells. This is frequently associated with plant defense mechanisms which, in many cases, might trigger plant cell programmed death (Pajerowska-Mukhtar and Dong 2009). Therefore, one of the possible explanations for this result is that Chunee roots might not have been able to recognize $G$. diazotrophicus as a benefic

Table 3. Proteins exclusively expressed by sugarcane SP70-1143 during interaction with Gluconacetobacter diazotrophicus ${ }^{\mathrm{a}}$

\begin{tabular}{lllcl}
\hline SUCEST cluster & \multicolumn{1}{c}{ Protein name } & \multicolumn{1}{c}{ Category } & MW & \multicolumn{1}{c}{ MS/MS peptides } \\
\hline SCCCLR1048F12.g & 14-3-3 Protein & Cellular communication/signal transduction & 9 & DSTLIMQLLR \\
SCEPLR1030G10.g & Receptor-like protein kinase & Cellular communication/signal transduction & 70 & RKSSMHK, LGLDWCK \\
SCJFLR1013F02.g & Glutamate-ammonia ligase & Amino acids metabolism & 41 & HKEHIAAYGEGNER \\
SCCCLR1072E07.g & Ascorbate peroxidase & Stress response & 27 & SGFEGAWTTNPLVFDNSYFK \\
SCRLFL1005D09.g & Receptor-like protein kinase & & & \\
& leucine-rich repeat domain & Cellular communication/signal transduction & 78 & VVSLSIPR \\
SCCCLR1C06C11.g & ATP citrate lyase & Lipids metabolism & 66 & AGKDLVSSLVSGLLTIGPR \\
SCCCLR1048E07.g & Tubulin $\alpha-1$ chain & Cellular dynamics & 47 & SVLKVVTMR, LVSQVISSLTASLR, \\
& & & AVFVDLETVIDEVR, \\
& & & AVFVDLEPTVIDEVRTGTYR \\
\hline
\end{tabular}

${ }^{\mathrm{a}} \mathrm{MW}$, protein theoretical molecular weight; MS/MS, tandem mass spectrometry.

Table 4. Proteins exclusively expressed by sugarcane Chunee during interaction with Gluconacetobacter diazotrophicus ${ }^{\mathrm{a}}$

\begin{tabular}{|c|c|c|c|c|}
\hline SUCEST cluster & Protein name & Category & MW & Peptide sequence \\
\hline SCCCLR1077D09.g & $\begin{array}{l}\text { 26S proteasome subunit } \\
6 \mathrm{~B}\end{array}$ & Protein metabolism, proteolysis & 45 & ENAPAIIFIDEVDAIATAR \\
\hline SCCCLR1065G03.g & $26 \mathrm{~S}$ proteasome subunit 7 & Protein metabolism, proteolysis & 47 & TMLEIVNQLDGFDAR \\
\hline SCVPLR1049C09.g & $\begin{array}{l}\text { Cell division control } \\
\text { protein } 48\end{array}$ & $\begin{array}{l}\text { Cell division/transport/ } \\
\text { stress/cellular communication }\end{array}$ & 90 & $\begin{array}{l}\text { KGDLFLVR, LDEVGYDDVGGVR, } \\
\text { IVSQLLTLMDGLK, } \\
\text { AHVIVMGATNRPNSIDPALR, } \\
\text { ETVVEVPNVSWEDIGGLENVKR, } \\
\text { AFEEAEKNAPSIIFIDEIDSIAPK }\end{array}$ \\
\hline SCCCLR2002G11.g & Histone $\mathrm{H} 2 \mathrm{~B}$ & $\begin{array}{l}\text { Cellular dynamics/stress/DNA } \\
\text { metabolism }\end{array}$ & 16 & $\begin{array}{l}\text { LVLPGELAK, QVHPDIGISSK, SVETYKIYIFK, } \\
\text { KTAAEKPVEENK }\end{array}$ \\
\hline SCBGLR1002A05.g & $\begin{array}{l}\text { Histone } \mathrm{H} 3.3 \text {, disease- } \\
\text { resistant-related protein }\end{array}$ & $\begin{array}{l}\text { Cellular dynamics/stress/DNA } \\
\text { metabolism }\end{array}$ & 19 & STELLIR, VLSHSSLK \\
\hline SCJFRT1007A12.g & $\begin{array}{l}\text { Ethylene receptor } \\
\text { homologue }\end{array}$ & $\begin{array}{l}\text { Plant growth and development/ } \\
\text { cellular communication }\end{array}$ & 85 & $\begin{array}{l}\text { GRGGYGGCSVSMEDLDVVR, } \\
\text { EIASWLLILSMVVFVSPVLAINGGGYPR }\end{array}$ \\
\hline SCCCLR2004H11.g & $\begin{array}{l}\text { Putative T-complex } \\
\text { protein 1, ETA subunit }\end{array}$ & Protein metabolism/stress & 60 & LAIGDLATQYFADRDIFCAGR \\
\hline SCAGLR2033E03.g & $\begin{array}{l}\text { Plasma membrane MIP } \\
\text { protein }\end{array}$ & Cellular dynamics/stress/transport & 30 & $\begin{array}{l}\text { GSGLGAEIIGTFVLVYTVFSATDAKR, } \\
\text { DSHVPILAPLPIGFAVFLVHLATIPITGTGINPAR }\end{array}$ \\
\hline
\end{tabular}

${ }^{\mathrm{a}} \mathrm{MW}$, protein theoretical molecular weight. 
bacterium, and then induced a robust defense mechanisms to limit its growth.

Protein Cdc48-like is a member of the AAA protein family (ATPases associated), involved in cell cycle regulation with roles in many cellular processes such as proteolysis, protein folding, vesicles trafficking, membrane fusion, cytoskeletal regulation, organelle biogenesis, and intracellular motility (Feiler et al. 1995; Patel and Latterich 1998). Interestingly, a previous study has demonstrated the synthesis of several vesicles from epidermal cells of sugarcane roots during interaction with G. diazotrophicus (Silva-Froufe 2003). Thus, we suggest that such membrane vesicles are also part of the plant defense system and that the Cdc-48-like protein in Chunee might have a role in this process.

Histones are the main protein components of chromatin. The identification of histones $\mathrm{H} 2 \mathrm{~B}$ and $\mathrm{H} 3.3$ also indicates that gene expression is being regulated, and it is feasible that genesilencing mechanisms are involved. Histones are proteins known to be highly post-translationally modified, and such modifications are crucial for its activity. Curiously, we have identified the peptide KTAAEKPVEENK of histone H2B with three acetylations (K1, K6, and K12) and two methylations (E9 and E10). The effects of such specific modifications in $\mathrm{H} 2 \mathrm{~B}$ function in sugarcane plants inoculated with $G$. diazotrophicus are unknown. However, they might indicate that a chromatin-remodeling process was taking place to turn on or off the expression of specific genes.

Finally, the identification of the ethylene receptor ETR2 is very intriguing because it described a clear correlation between ethylene-responsive pathways and biotic stresses. The activetion of ethylene receptors culminates with a decrease of stress responses and plant defense mechanisms, among others. Thus, it favors bacteria-plant interactions. Accordingly, a previous study has shown that a sugarcane ethylene receptor mRNA is induced by $G$. diazotrophicus stimuli; thus, our results showing the increase of this protein level are in agreement with the previous results for mRNA quantification (Cavalcante et al. 2007).

\section{Sugarcane genotypes SP70-1143 and Chunee expressed different proteins in response to G. diazotrophicus interaction.}

The sets of proteins expressed by each genotype during interaction with $G$. diazotrophicus showed that they respond differentially to the bacterium.

On one hand, SP70-1143 mainly expressed proteins for stress resistance and signaling cascades that might allow bacterial colonization. Specific mechanisms of plant defense against bacteria were not detected in this sample (Table 3). On the other hand, Chunee altered the expression of proteins involved in defense responses (Table 4). Altogether, these results suggested that, while SP70-1143 seems to have efficiently recognized $G$. diazotrophicus as a beneficial partner, Chunee manage to deal with the bacterium by activating defensive strategies.

\section{Identification of $G$. diazotrophicus proteins from sugarcane root samples.}

In an attempt to identify $G$. diazotrophicus proteins expressed by $G$. diazotrophicus cells in intimate contact with sugarcane, roots of sugarcane SP70-1143 and Chunee were analyzed for the presence of bacterial proteins after $24 \mathrm{~h}$ of bacterial inoculation. Thus, we have searched all the MS/MS spectra acquired from root samples against the $G$. diazotrophicus database. We have identified $8 \mathrm{G}$. diazotrophicus proteins from SP70-1143 roots and 25 from Chunee samples. Overall, 30 different bacterial proteins were identified (Table 5). These are extremely interesting findings because $G$. diazotrophicus proteins expressed in planta were not previously described. Among them, nine were not previously detected in proteomic analysis of $G$. diazotrophicus grown under several different conditions (Lery et al. 2008a and b), indicating that their expression is exclusively induced during direct interaction with sugarcane.

These nine proteins were a component of the potassium transport system, the putative cell volume regulator protein A, the chemotaxis protein methyltransferase CheR, a cystathione gamma synthase, a glutathione $S$-transferase, the UDP glucose 6-dehydrogenase (UDPDH), a nucleoside 2-deoxyribosyltransferase, an outer-membrane protein, and a putative transporter.

Within sugarcane, bacterial cells face a new osmotic environment and, in order to adapt to such conditions, they need to activate osmosensing mechanisms to modulate osmoregulatory responses. One of these bacterial osmosensing mechanisms is the loss of turgor pressure. This involves, among other things, changes of cytoplasmic volume and in the internal concentration of one or more solutes, including $\mathrm{K}^{+}$, which serve as signals to activate expression of osmoregulated genes (Ballal et al. 2007; Kramer 2009; Sleator and Hill 2002). Consistent with these observations, G. diazotrophicus within sugarcane expressed the products of loci GDI1813 and GDI2385, respectively, a putative cell volume regulation protein A, and a potassium transport system protein (low-affinity $\mathrm{K}$ transport system, Kup homologue), strongly indicating that the bacterium sensed the osmostress and responded appropriately. This is also in line with the differential expression by the bacterium during the coculture interaction with SP70 of a KdpE homologue, involved in $\mathrm{K}^{+}$uptake. As mentioned above, the maintenance of $\mathrm{K}^{+}$homeostasis is an essential branch of the osmoresponse pathway and might prepare the bacterial cells in co-culture to enter the high osmolarity medium within the sugarcane root (Sleator and Hill 2002). Additionally, it was shown that the potassium uptake system Kup (homologue of GDI2385) is essential for Sinorhizobium meliloti colonization of alfalfa plants (Dominguez-Ferreras et al. 2009). Therefore, it reinforces the relevance of these proteins for a fruitful association of $G$. diazotrophicus with sugarcane.

Not by chance, G. diazotrophicus also expressed the product of locus, GDI0525, a glutamine synthetase that is involved in the synthesis of $\mathrm{N}$-acetylglutaminylglutamine amide and glutamate which, in $S$. meliloti cells, function as osmolytes and facilitate growth in elevated osmolarities. Moreover, in E. coli, endogenous glutamate synthesis helps to counterbalance the rapid $\mathrm{K}^{+}$influx after osmotic upshock (Sleator and Hill 2002).

In addition to the osmotic stress response, G. diazotrophicus expressed a mechanism to deal with oxidative stress within sugarcane roots, as suggested by the differential expression of a glutathione- $S$-transferases and by other proteins, not specifically expressed by the bacterial cells in planta but also involved in the process; namely catalase, peroxiredoxin protein, and superoxide dismutase. It has been demonstrated that oxidative burst is an early event in plant defense against symbiotic bacteria and pathogens (Baron and Zambryski 1995; Vuilleumier 1997). Another protein that might be part of a redox regulation system is cystathione gamma synthase, also expressed in planta. This enzyme participates on sulfur, cysteine, and methionine metabolism. Such protein is very interesting because the methionine pathway was previously shown to be regulated during the $G$. diazotrophicus interaction with sugarcane (discussed below).

The G. diazotrophicus response to sugarcane also seems to involve alterations of bacterial cell envelope composition. This is suggested by the identification of an outer-membrane product of GDIA_2347, which has been annotated as lactamase-B, and a putative cytoplasmic membrane protein product of loci GDI3457. Lactamase- $B$ is a member of the metallo- $\beta$-lac- 
tamase superfamily, which includes proteins that inactivate most $\beta$-lactam antibiotics and hydrolyze thiol-ester, phosphodiester, and sulfuric ester bonds (Bebrone 2007). The product of GDI3457, on the other hand, is a putative secondary transporter of the major facilitator superfamily (MSF) for small solutes in response to chemiosmotic ion gradients. MSF protein functions are highly diverse and include drug efflux systems and several permeases that allow solute exchanges between the cells and the environment (Pao et al. 1998).

The extensive signaling between $G$. diazotrophicus and sugarcane is further exemplified by the expression of the bacterium of CheR, a cytoplasmic chemotaxis protein, expressed in planta. In E. coli, CheR is responsible for chemoreceptor methylation in the adaptation process to attractant signals, a step of funda- mental importance for bacterial cells that perceive a concentration gradient of chemoattractants (Falke et al. 1997).

In addition to oxidative and osmostress responses, another defense-related strategy used by the bacterium in planta is suggested by differential expression of the product of GDI1140, a putative UDPDH. This is an enzyme of the biosynthesis pathway of colanic acid, a molecule which, in E. coli, Pseudomonas aeruginosa, and Vibrio cholerae, has been shown to be important for capsule formation (Stevenson et al. 1996). In Pseudomonas spp., lung infection capsules increase the ability of the bacterium to adhere to substrates and, in turn, to form biofilm, which is an important factor in its persistence in the tissue (Lam et al. 1980). Moreover, UDPDH is involved in the interaction between $V$. fischeri and its squid host, where success-

Table 5. Proteins expressed by Gluconacetobacter diazotrophicus cells in sugarcane roots ${ }^{\mathrm{a}}$

\begin{tabular}{|c|c|c|c|c|c|c|c|}
\hline $\begin{array}{l}\text { Accession } \\
\text { no. }\end{array}$ & Locus & Protein & MW & Pid & PM & Peptides & Sample \\
\hline \multicolumn{8}{|l|}{ In planta ${ }^{\mathrm{b}}$} \\
\hline 162148168 & GDI2385 & Potassium transport system protein & 23 & 70 & 2 & GLIMNRQK, IPQGGWVPVLLGIALTLMMTTWK & $\begin{array}{l}\text { SP-70 e } \\
\text { Chunee }\end{array}$ \\
\hline 162147597 & GDI1813 & $\begin{array}{l}\text { Putative cell volume regulation } \\
\text { protein A }\end{array}$ & 25 & 65 & 1 & LGCPVMLVDTCTGALAPASRAGIPILK & SP-70 \\
\hline 162147471 & GDI1687 & $\begin{array}{l}\text { Putative chemotaxis protein } \\
\text { methyltransferase }\end{array}$ & 31 & 31 & 1 & NHFTHLKEFVVPR & Chunee \\
\hline 162146602 & GDI0780 & $\begin{array}{l}\text { Putative cystathionine gamma- } \\
\text { synthase }\end{array}$ & 28 & 45 & 1 & AYRPATRLLHSGVER & SP-70 \\
\hline 162148550 & GDI2774 & Putative glutathionine S-transferase & 23 & 25 & 1 & TPEFLR & Chunee \\
\hline 162147594 & GDI1810 & $\begin{array}{l}\text { Putative nucleoside } 2 \text { - } \\
\text { deoxyribosyltransferase }\end{array}$ & 21 & 31 & 1 & IAIAELAR & Chunee \\
\hline 162146935 & GDI1140 & $\begin{array}{l}\text { Putative UDP-glucose 6- } \\
\text { dehydrogenase }\end{array}$ & 46 & 23 & 1 & QIARAMTDYAVIVTK & Chunee \\
\hline 162149225 & GDI3457 & Putative transporter protein & 34 & 34 & 1 & VVATTVPR & Chunee \\
\hline 209544487 & GDIA2347 & Putative outer-membrane protein & 38 & 22 & 1 & LLSILR & Chunee \\
\hline \multicolumn{8}{|c|}{ Others } \\
\hline 162145880 & GDI0041 & Outer-membrane protein & 40 & 65 & 3 & SSPNFPDGR, IEVDGYTDNSAAHPGPR, RVEIILH & $\begin{array}{l}\text { SP-70 e } \\
\text { Chunee }\end{array}$ \\
\hline 162145915 & GDI0079 & Catalase & 55 & 63 & 1 & LVSNIVGHVLQGVEEPVLSR & Chunee \\
\hline 162146116 & GDI0286 & $\begin{array}{l}\text { Bifunctional } \\
\text { transaldolase/phosoglucose } \\
\text { isomerase }\end{array}$ & 102 & 26 & 1 & ASAASVPPALNPGVVLGTVLGVAATQFGR & Chunee \\
\hline 162146281 & GDI0456 & Chemoreceptor McpA & 57 & 23 & 2 & ISASFARRPR, MTKESQIVER & SP-70 \\
\hline 162146350 & GDI0525 & Glutamine synthetase & 53 & 118 & 3 & $\begin{array}{l}\text { LIPGFEAPVLLAYSAR, HHHEVAQSQHELGTK, } \\
\text { RLIPGFEAPVLLAYSAR }\end{array}$ & Chunee \\
\hline 162146401 & GDI0576 & Peroxiredoxin protein & 20 & 46 & 1 & ATFLVDPEGIIR & Chunee \\
\hline 162146520 & GDI0696 & F0F1 ATP synthase subunit $\beta$ & 53 & 58 & 1 & TVIIQELINNIAK & Chunee \\
\hline 162147070 & GDI1275 & Outer-membrane protein & 28 & 24 & 1 & FNPYVGVGATLAFFHNESPAGGLVK & Chunee \\
\hline 162147085 & GDI1290 & Pyruvate kinase & 51 & 58 & 1 & TVETVVDQAIESTVASSLAR & Chunee \\
\hline 162147166 & GDI1371 & $\begin{array}{l}\text { Polynucleotide } \\
\text { phosphorylase/polyadenylase }\end{array}$ & 76 & 75 & 2 & $\begin{array}{l}\text { TADFGAFVNFLGAR, } \\
\text { EAVLAALATEGLDVTAAKPILKDLEADVVR }\end{array}$ & Chunee \\
\hline 162147179 & GDI1384 & Biopolymer transport ExbB protein & 36 & 53 & 1 & NFAADLQSILLGGFR & Chunee \\
\hline 162147833 & GDI2049 & Chaperonin GroEL & 58 & 141 & 4 & $\begin{array}{l}\text { VGGSTEVEVK, } \\
\text { TALQDASSVAGLLITTEAMVAEKPEKK, } \\
\text { TALQDASSVAGLLITTEAMVAEKPEK, } \\
\text { VLESNDYNYGFDAQIGDYKDLVAAGIIDPTK }\end{array}$ & Chunee \\
\hline 162147969 & GDI2185 & Outer-membrane lipoprotein & 40 & 78 & 2 & TYLVFFDWDR, TYLVFFDWDRSDLTAR & Chunee \\
\hline 162148085 & GDI2302 & $\begin{array}{l}\text { Glyceraldehyde-3-phosphate } \\
\text { dehydrogenase }\end{array}$ & 36 & 38 & 1 & GILAYNTAPLVSSDFNHSIASSTFDATETALVDGGK & Chunee \\
\hline 162148355 & GDI2572 & $\begin{array}{l}\text { 5-Methyltetrahydropteroyltriglut- } \\
\text { amate-homocysteine } \\
\text { methyltransferase MetE }\end{array}$ & 85 & 131 & 5 & $\begin{array}{l}\text { ETTCRQIAYAIR, LLPVYVAILR, GGGFDPLTLLPR, } \\
\text { GMLTGPVTILNWSFVR, } \\
\text { AQGIETRPVLLGPVSYLLLGK }\end{array}$ & $\begin{array}{l}\text { SP-70 e } \\
\text { Chunee }\end{array}$ \\
\hline 162148832 & GDI3061 & Hypothetical protein GDI3061 & 57 & 26 & 1 & IRDSLPR & $\begin{array}{l}\text { SP-70 e } \\
\text { Chunee }\end{array}$ \\
\hline 162149101 & GDI3331 & 50S ribosomal protein L9 & 21 & 94 & 2 & $\begin{array}{l}\text { TQVILENPIKQLGLYDVR, } \\
\text { SAVELILLQRVENLGQMGDVVK }\end{array}$ & Chunee \\
\hline 162149176 & GDI3406 & Elongation factor $\mathrm{Tu}$ & 43 & 65 & 4 & $\begin{array}{l}\text { GVVNVGDEIEIVGLR, QVGVPALVVFLNK, } \\
\text { ELLSAYQFPGDDIPIIK, } \\
\text { DLMDAVDAYIPQPERPVDRPFLMPIEDVFSISGR }\end{array}$ & $\begin{array}{l}\text { SP-70 e } \\
\text { Chunee }\end{array}$ \\
\hline 162149228 & GDI3460 & 30S ribosomal protein $\mathrm{S} 1$ & 63 & 30 & 1 & DVTPLMGVPQPFQILK & Chunee \\
\hline 162149428 & GDI3666 & Hypothetical protein GDI3666 & 42 & 154 & 2 & NWNIVLTNIIR, TLIPLSFQFASFDGR & Chunee \\
\hline 209542569 & GDIA0387 & Superoxide dismutase & 22 & 32 & 1 & AFELPTLPFQTNALAAR & Chunee \\
\hline
\end{tabular}

${ }^{a}$ MW, protein theoretical molecular weight; Pid score, mascot protein identification score; PM, number of peptides matched.

${ }^{\mathrm{b}}$ Exclusively expressed in planta. 
ful colonization also requires biofilm production (Ariyakumar and Nishiguchi 2009).

In line with these facts, we hypothesize that the expression of UDPDH by $G$. diazotrophicus within the sugarcane roots might help the cells to form biofilm as an extra measure of protection. Consistent with this observation, it has been shown that individual $G$. diazotrophicus cells within the xylem vessel and protoxylem of sugar cane genotype SP 70-1143 presented electron-lucent haloes around them and, in some cases, many cells appeared imbedded in a transparent matrix (James et al. 2001). An electron-transparent structure of unknown composition has also been observed around cells in many other bacterium-host plant systems and surrounding $E$. coli cells in bladder epithelial cells cytoplasm. Interestingly, in the E. coli infection, the material was identified as a polysaccharide-rich matrix, consistent with the formation of bacterial biofilm (Anderson et al. 2003). Thus, it seems that formation of biofilm is a common survival strategy for microorganisms to persist within plants and animals, thereby avoiding the defense mechanisms elicited by the hosts against the microbial invaders.

\section{Concluding remarks.}

This is the first report regarding molecular characterization of early events $(24 \mathrm{~h})$ of the $G$. diazotrophicus-sugarcane interaction. We have convincingly shown that $G$. diazotrophicus perceives and responds similarly to the interaction with two distinct sugarcane genotypes in co-culture conditions. However, genotype-specific molecular responses were observed. SP70-1143 expressed proteins involved in cellular adaptation and signaling systems that enabled bacterial root colonization. Chunee, on the other hand, elicited robust defense mechanisms against $G$. diazotrophicus cells, thereby avoiding the establishment of a successful interaction.

Moreover, this is, to our knowledge, the first report on proteins expressed by G. diazotrophicus in close contact with sugarcane plants, suggesting that they are upregulated by host signals. In all, 30 different bacterial proteins were described to be expressed by bacterial cells during the initial $24 \mathrm{~h}$ of the process of sugarcane roots colonization. Among these, nine have not been described in prior proteomic analysis of $G$. diazotrophicus. Therefore, these proteins are suggested to be regulated by host signals. They comprise functions involved in chemotaxis, cell differentiation, and osmotic and oxidative stress regulation.

Interestingly, some of the results presented herein suggest that the G. diazotrophicus-SP70-1143 sugarcane interaction shares peculiar features with other symbiotic relationships, such as the formation of biofilm by the bacterial cells in planta as an extra measure of protection against the host defense mechanisms.

Supplementary Table 1 provides raw data on bacterial and plant protein identification that might be important for enriching the existing proteomic databases of $G$. diazotrophicus and sugarcane as well as for researchers interested in finding information on specific proteins.

\section{MATERIALS AND METHODS}

Bacterial strains, media, and growth conditions.

G. diazotrophicus, lineage PAL5 (BR11281), was precultured in LGI-P medium $\left(\mathrm{K}_{2} \mathrm{HPO}_{4}\right.$ at $0.2 \mathrm{~g} /$ liter, $\mathrm{KH}_{2} \mathrm{PO}_{4}$ at $0.6 \mathrm{~g} /$ liter, $\mathrm{MgSO}_{4} \cdot 7 \mathrm{H}_{2} \mathrm{O}$ at $0.2 \mathrm{~g} / \mathrm{liter}, \mathrm{CaCl}_{2} \cdot 2 \mathrm{H}_{2} \mathrm{O}$ at $0.02 \mathrm{~g} / \mathrm{liter}$, $\mathrm{Na}_{2} \mathrm{MoO}_{4} \cdot 2 \mathrm{H}_{2} \mathrm{O}$ at $0.002 \mathrm{~g} / \mathrm{liter}, \mathrm{FeCl}_{3} \cdot 6 \mathrm{H}_{2} \mathrm{O}$ at $0.01 \mathrm{~g} /$ liter, bromothymol blue [0.5\%] at $5 \mathrm{ml} /$ liter in $0.2 \mathrm{M} \mathrm{KOH}$, and sacarose at $10 \mathrm{~g} /$ liter) containing $10 \mathrm{mM}\left(\mathrm{NH}_{4}\right)_{2} \mathrm{SO}_{4}$ for $36 \mathrm{~h}$ (exponential phase) at $30^{\circ} \mathrm{C}$ and $400 \mathrm{rpm}$. Cells were harvested by centrifugation $\left(18,000 \times g, 10 \mathrm{~min}, 4^{\circ} \mathrm{C}\right)$ and washed in phosphate-buffered saline buffer. Bacteria were resuspended in the same volume of a 10-fold diluted Murashige-Skoog me$\operatorname{dium}(\mathrm{MS} / 10)\left(0.75 \mathrm{mM} \mathrm{MgSO}_{4}, 0.65 \mathrm{mM} \mathrm{KH}_{2} \mathrm{PO}_{4}, 1.5 \mathrm{mM}\right.$ $\mathrm{CaCl}_{2}, 0.05 \mathrm{mM} \mathrm{CoCl} 2 \cdot 6 \mathrm{H}_{2} \mathrm{O}, 0.16 \mathrm{mM} \mathrm{CuSO} \mathrm{Cu}_{4} \cdot 5 \mathrm{H}_{2} \mathrm{O}, 45$ mM FeNaEDTA, $23 \mathrm{mM} \mathrm{H}_{3} \mathrm{BO}_{3}, 2.5 \mathrm{mM} \mathrm{KI}, 50 \mathrm{mM} \mathrm{MnSO} \mathrm{M}_{4}$. $\mathrm{H}_{2} \mathrm{O}, 0.26 \mathrm{mM} \mathrm{Na}_{2} \mathrm{MoO}_{4} \cdot 2 \mathrm{H}_{2} \mathrm{O}, 0.36 \mathrm{mM} \mathrm{ZnSO} \mathrm{Z}_{4} \cdot 7 \mathrm{H}_{2} \mathrm{O}, 4.6$ $\mathrm{mM} \mathrm{MnCl} \mathrm{M}_{2} \cdot 4 \mathrm{H}_{2} \mathrm{O}, 0.05 \mathrm{mM} \mathrm{NH}_{4} \mathrm{NO}_{3}, 2 \mathrm{mM} \mathrm{KNO}$, and sucrose at $2 \mathrm{~g} /$ liter) and incubated for $8 \mathrm{~h}$ at $30^{\circ} \mathrm{C}$ and $400 \mathrm{rpm}$.

\section{In vitro plant growth and bacterial co-cultivation.}

The sugarcane genotypes SP70-1143 (high inputs of N from $\mathrm{BNF}$ ) and Chunee (low inputs of $\mathrm{N}$ from BNF) were used throughout this work. Sugarcane plantlets free of microorganisms were obtained by sterile meristem culture and micropropagated according to the method of Hendre and associates (1983).

In vitro-grown rooted sugarcane plantlets were inoculated as described before (Reis et al. 1999). Briefly, rooted plantlets were starved in the MS/10 medium for 7 days and then inoculated with $0.1 \mathrm{ml}$ of a suspension containing $10^{5}$ bacterial cells. Controls were inoculated with medium only. All plants were maintained at $30^{\circ} \mathrm{C}$ with an irradiance of $60 \mu \mathrm{mol}$ photons $\mathrm{m}^{-2}$ $\mathrm{s}^{-1}$ for $12 \mathrm{~h} \mathrm{day}^{-1}$. Then, $24 \mathrm{~h}$ after the inoculation, plants were harvested and both the roots and culture medium were collected in duplicates. A pool of six plantlets constituted each sample. The culture medium was centrifuged $10 \mathrm{~min}$ at 10,000 rpm in order to recover bacterial cells.

Examination of bacterial colonization was estimated by the most probable number, according to the methods of Reis and associates (1994).

\section{Metabolic labeling of bacterial and plant cells by incorporation of ${ }^{14} \mathrm{~N} /{ }^{15} \mathrm{~N}$ isotopes.}

Metabolic labeling with ${ }^{14} \mathrm{~N} /{ }^{15} \mathrm{~N}$ was performed through the incorporation of ${ }^{14} \mathrm{~N} /{ }^{15} \mathrm{~N}$ isotopes during cellular growth in medium containing ${ }^{14} \mathrm{~N}$ or ${ }^{15} \mathrm{~N}$ salts. Samples grown in ${ }^{14} \mathrm{~N}$ media (natural abundance of nitrogen isotopes) were called "nonlabeled" and those grown in media containing ${ }^{15} \mathrm{~N} 98 \%$ enriched were called "labeled". For bacterial labeling, cells were grown as described above with the replacement of $\mathrm{NH}_{4} \mathrm{NO}_{3}$ and $\mathrm{KNO}_{3}$ by ${ }^{15} \mathrm{NH}_{4}{ }^{15} \mathrm{NO}_{3}$ and $\mathrm{K}^{15} \mathrm{NO}_{3}$ in equal amounts of ${ }^{14} \mathrm{~N}$ media (described above). ${ }^{15} \mathrm{~N}$-labeled plants were obtained by substitution of $\mathrm{NH}_{4} \mathrm{NO}_{3}$ and $\mathrm{KNO}_{3}$ by ${ }^{15} \mathrm{NH}_{4}{ }^{15} \mathrm{NO}_{3}$ and $\mathrm{K}^{15} \mathrm{NO}_{3}$ in equal amounts of ${ }^{14} \mathrm{~N}$ media during multiplication and rooting periods. The ${ }^{14} \mathrm{~N}$-labeled bacterium and plants were grown in parallel under the same conditions in the presence of salts containing ${ }^{14} \mathrm{~N}$ and ${ }^{15} \mathrm{~N}$ isotopes at their natural abundance. Reverse-labeling and two independent experiments were performed. ${ }^{15} \mathrm{~N}$ salts were purchased from Cambridge Isotope Laboratories Inc. (Andover, MA, U.S.A.).

\section{Protein extraction methods.}

Optical density at $600 \mathrm{~nm}$ of the bacterial suspension collected after the experiment was obtained by spectrophotometrical analysis, and normalized volumes of bacterial cells from test and control samples (labeled and nonlabeled) were mixed, resuspended in SDS-PAGE Laemmli buffer (Laemmli 1970), and heated for $10 \mathrm{~min}$ at $100^{\circ} \mathrm{C}$. A clear lysate was obtained after centrifugation at $14,000 \times g$ for $1 \mathrm{~h}$ at $4^{\circ} \mathrm{C}$. The pellet was resuspended in a solution containing $7 \mathrm{M}$ urea, $2 \mathrm{M}$ thiourea, $1 \%$ chaps, and a mixture of protease inhibitors (GE Healthcare, Piscataway, NJ, U.S.A.).

Plant samples were weighted immediately after the experiment. In all, $100 \mathrm{mg}$ of tissues from test and control samples (labeled and nonlabeled) were mixed, frozen in $\mathrm{N}_{2}$ liquid, and macerated. The macerates were ground to fine powder with the Sample Grinding Kit (GE Healthcare) and proteins were further extracted with the Plant total protein extraction kit (Sigma- 
Aldrich, St Louis). Clear lysates were obtained after centrifugation at $14,000 \times g$ for $30 \mathrm{~min}$ at $4^{\circ} \mathrm{C}$.

\section{Protein separation and in gel digestion.}

SDS-PAGE was performed on a $12.5 \%$ polyacrylamide gel in a mini Protean II system (Bio-Rad, Munich). Approximately $20 \mu \mathrm{g}$ of protein per lane was applied onto the gels. Gels were stained with Coomassie Brilliant Blue G-250 and images were acquired in LabScan 5 (GE Healthcare). SDS-PAGE gels were sliced in 5 to 10 regular pieces. Excision and processing of protein spots from SDS-PAGE gels were performed as previously described (Lery et al. 2008a).

\section{ESI-Q-TOF analysis.}

LC-MSMS was performed in a Q-TOF Ultima API mass spectrometer (Micromass, Manchester, U.K.) to analyze tryptic peptides from proteins separated by SDS-PAGE. A nanoflow ESI source was used with a lockspray source for lockmass measurements during the entire chromatographic run. Digested proteins were desalted online using a Waters Opti-Pak C18 trap column. The mixture of trapped peptides was then separated by elution with a water/ACN $0.1 \%$ formic acid gradient through a Nanoease C18 (75- $\mu \mathrm{m}$ i.d.) capillary column. Data were acquired in data-dependent mode, and multiple-charged peptides ions $(+2$ and +3$)$ were automatically mass selected and dissociated in MS/MS experiments. Typical LC and ESI conditions were a 200-nl/min flow, a $3-\mathrm{kV}$ nanoflow capillary voltage, a $100^{\circ} \mathrm{C}$ block temperature, and a $100-\mathrm{V}$ cone voltage.

\section{Protein identification.}

Mascot Distiller file Q-TOF.opt default parameters (Matrix Science, Boston) were used for spectra processing and lock spray mass 784.8230 over three scans and tolerance of $\pm 0.3 \mathrm{Da}$ was used for calibration. The MS/MS spectra were processed using the Mascot Distiller software (version 2.3.0; Matrix Science) and the peak lists generated were searched against the $G$. diazotrophicus (Bertalan et al. 2009) or National Center for Biotechnology Information database using the MASCOT search engine tool (Matrix Science). Protein identifications from root samples were performed with a taxonomy filter for Arabidopsis thaliana entries, due to the high level of database annotation.

Database searches were performed with tryptic specificity allowing one missed cleavage and a mass tolerance of $0.1 \mathrm{Da}$ for parent and fragment ions. Oxidation of methionine residues and carbamidomethylation at cysteine residues were considered as variable modifications; other modifications were included if clearly described below. Every peptide with $P<0.05$ was considered for manual inspection. Protein identification was based on at least one unique peptide (a peptide sequence exclusive of one protein hit of the database). If a protein appeared under different names or accession numbers, the entry with the highest sequence coverage was selected.

\section{Relative quantification and statistical analysis.}

For relative protein quantification based on metabolic ${ }^{14} \mathrm{~N} /{ }^{15} \mathrm{~N}$ labeling, the Mascot Distiller quantification package (Matrix Science) was used. The quantitation.xlm file (available at the Matrix Science homepage in July 2009) was modified according to the specific requirements. Briefly, the percentage of ${ }^{15} \mathrm{~N}$ incorporation was set to $25 \%$ (bacterial samples) or $50 \%$ (plant samples), a quadratic integration of precursor peak intensities across a range of survey scans was performed over the entire isotopic envelope, a minimum of one unique peptide was required, the protein ratio was calculated as the geometric average of peptide ratios, outliers were automatically removed, and normalization was done in relation to the average. The standard deviation of the quantitative value for the protein ratio was obtained in order to check for outliers and the consistency of the measures for a normal distribution. Significant changes in protein expression levels were reported if the protein ratio was significantly different from unity. The comparison test is $|x-\mu| \leq t(s / \sqrt{ } N)$, where $N$ is the number of recorded peptide ratios, $x$ is the mean of the peptide ratios, and $s$ is the standard deviation. The true value of the ratio $\mu$ is 1 and $t$ is the Student's value taken for $N-1$ degrees of freedom and a two-sided confidence level of $95 \%$. Unpaired peptides indicated a protein expressed exclusively in one sample and were also included in the differential expression list.

\section{ACKNOWLEDGMENTS}

We thank Laboratório Naciona de Luz Síncroton for the Q-TOF Ultima utilization; P. R. F. Dias for excellent support with plant maintenance; and Fundação de Amparo à Pesquisa do Rio de Janeiro, Conselho Nacional de Desenvolvimento Científico e Tecnológico, Coordenação de Aperfeiçoamento de Pessoal de Nível Superior and International Foundation for Science for financial support.

\section{LITERATURE CITED}

Altendorf, K., Voelkner, P., and Puppe, W. 1994. The sensor kinase KdpD and the response regulator $\mathrm{KdpE}$ control expression of the kdpFABC operon in Escherichia coli. Res. Microbiol. 145:374-381.

Anderson, G. G., Palermo, J. J., Schilling, J. D., Roth, R., Heuser, J., and Hultgren, S. J. 2003. Intracellular bacterial biofilm-like pods in urinary tract infections. Science 301:105-107.

Arencibia, A. D., Vinagre, F., Estevez, Y., Bernal, A., Perez, J., Cavalcanti, J., Santana, I., and Hemerly, A. S. 2006. Gluconacetobacter diazotrophicus elicits a sugarcane defense response against a pathogenic bacteria Xanthomonas albilineans. Plant Signal. Behav. 1:265-273.

Ariyakumar, D. S., and Nishiguchi, M. K. 2009. Characterization of two host-specific genes, mannose-sensitive hemagglutinin (mshA) and uridyl phosphate dehydrogenase (UDPDH) that are involved in the Vibrio fischeri-Euprymna tasmanica mutualism. FEMS (Fed. Eur. Microbiol. Soc.) Microbiol. Lett. 299:65-73.

Baldo, A., Norelli, J. L., Farrell, R. E., Jr., Basset, C., Aldwinckle, H. S., and Malnoy, M. 2010. Identification of genes differentially expressed during interaction of resistant and susceptible apple cultivars (Malus $\times$ domestica) with Erwinia amylovora. BMC Plant Biol. 10:1.

Ballal, A., Basu, B., and Apte, S. K. 2007. The Kdp-ATPase system and its regulation. J. Biosci. 32:559-568.

Baron, C., and Zambryski, P. C. 1995. The plant response in pathogenesis, symbiosis, and wounding: Variations on a common theme? Annu. Rev. Genet. 29:107-129.

Bebrone, C. 2007. Metallo-beta-lactamases (classification, activity, genetic organization, structure, zinc coordination) and their superfamily. Biochem. Pharmacol. 74:1686-1701.

Becker, G. W. 2008. Stable isotopic labeling of proteins for quantitative proteomic applications. Brief. Funct. Genomics Proteomics 7:371-382.

Bellone, C. H., De Bellone, S. D. V. C., Pedraza, R. O., and Monzon, M. A. 1997. Cell colonization and infection thread formation in sugar cane roots by Acetobacter diazotrophicus. Soil Biol. Biochem. 29:965967.

Bertalan, M., Albano, R., de Padua, V., Rouws, L., Rojas, C., Hemerly, A., Teixeira, K., Schwab, S., Araujo, J., Oliveira, A., Franca, L., Magalhaes, V., Alqueres, S., Cardoso, A., Almeida, W., Loureiro, M. M., Nogueira, E., Cidade, D., Oliveira, D., Simao, T., Macedo, J., Valadao, A., Dreschsel, M., Freitas, F., Vidal, M., Guedes, H., Rodrigues, E., Meneses, C., Brioso, P., Pozzer, L., Figueiredo, D., Montano, H., Junior, J., de Souza Filho, G., Martin Quintana Flores, V., Ferreira, B., Branco, A., Gonzalez, P., Guillobel, H., Lemos, M., Seibel, L., Alves-Ferreira, M., Sachetto-Martins, G., Coelho, A., Santos, E., Amaral, G., Neves, A., Pacheco, A. B., Carvalho, D., Lery, L., Bisch, P., Rossle, S. C., Urmenyi, T., Rael Pereira, A., Silva, R., Rondinelli, E., von Kruger, W., Martins, O., Baldani, J. I., and Ferreira, P. C. 2009. Complete genome sequence of the sugarcane nitrogen-fixing endophyte Gluconacetobacter diazotrophicus Pal5. BMC Genomics 10:450.

Beynon, R. J., and Pratt, J. M. 2005. Metabolic labeling of proteins for proteomics. Mol. Cell. Proteomics 4:857-872.

Bindschedler, L. V., Palmblad, M., and Cramer, R. 2008. Hydroponic isotope labelling of entire plants (HILEP) for quantitative plant proteomics: An oxidative stress case study. Phytochemistry 69:1962-1972. 
Blanco, Y., Blanch, M., Pinon, D., Legaz, M. E., and Vicente, C. 2005. Antagonism of Gluconacetobacter diazotrophicus (a sugarcane endosymbiont) against Xanthomonas albilineans (pathogen) studied in alginate-immobilized sugarcane stalk tissues. J. Biosci. Bioeng. 99:366371

Brencic, A., and Winans, S. C. 2005. Detection of and response to signals involved in host-microbe interactions by plant-associated bacteria. Microbiol. Mol. Biol. Rev. 69:155-194.

Briegel, A., Ortega, D. R., Tocheva, E. I., Wuichet, K., Li, Z., Chen, S. Muller, A., Iancu, C. V., Murphy, G. E., Dobro, M. J., Zhulin, I. B., and Jensen, G. J. 2009. Universal architecture of bacterial chemoreceptor arrays. Proc. Natl. Acad. Sci. U.S.A. 106:17181-17186.

Brito, B., Aldon, D., Barberis, P., Boucher, C., and Genin, S. 2002. A signal transfer system through three compartments transduces the plant cell contact-dependent signal controlling Ralstonia solanacearum hrp genes. Mol. Plant-Microbe Interact. 15:109-119.

Cabiscol, E., Tamarit, J., and Ros, J. 2000. Oxidative stress in bacteria and protein damage by reactive oxygen species. Int. Microbiol. 3:3-8.

Carrondo, M. A. 2003. Ferritins, iron uptake and storage from the bacterioferritin viewpoint. EMBO (Eur. Mol. Biol. Organ.) J. 22:19591968.

Cavalcante, J. J., Vargas, C., Nogueira, E. M., Vinagre, F., Schwarcz, K., Baldani, J. I., Ferreira, P. C., and Hemerly, A. S. 2007. Members of the ethylene signalling pathway are regulated in sugarcane during the association with nitrogen-fixing endophytic bacteria. J. Exp. Bot. 58:673686.

Cavalcante, V. A., and Döbereiner, J. 1988. A new acid-tolerant nitrogenfixing bacterium associated with sugarcane. Plant Soil 108:23-31.

Crespi, M., and Frugier, F. 2008. De novo organ formation from differentiated cells: Root nodule organogenesis. Sci. Signal. 1:re11.

da Silva, L. G. 2005. Aspectos estruturais da interação de bactérias diazotróficas endofíticas e cana-de-açúcar (Saccharum hyb.) Campos dos Goytacazes, Universidade Estadual do Norte Fluminense.

Den Herder, G., and Parniske, M. 2009. The unbearable naivety of legumes in symbiosis. Curr. Opin. Plant Biol. 12:491-499.

de Wit, P. J. 2007. How plants recognize pathogens and defend themselves. Cell. Mol. Life Sci. 64:2726-2732.

Döbereiner, J., Reis, V. M., Paula, M. A., and Olivares, F. L. 1993. Endophytes diazotrophs in sugar cane, cereals and tuber plants. Pages 671676 in: New Horizons in Nitrogen Fixation. R. Palacios, J. Mora, and W. E. Newton, eds. Kluwer Academic Publishers, Dordrecht, The Netherlands.

Dominguez-Ferreras, A., Munoz, S., Olivares, J., Soto, M. J., and Sanjuan, J. 2009. Role of potassium uptake systems in Sinorhizobium meliloti osmoadaptation and symbiotic performance. J. Bacteriol. 191:21332143.

Dong, Z., Canny, M. J., McCully, M. E., Roboredo, M. R., Cabadilla, C. F., Ortega, E., and Rodes, R. 1994. A nitrogen-fixing endophyte of sugarcane stems (a new role for the apoplast). Plant Physiol. 105:11391147.

Dos Santos, M. F., Muniz de Padua, V. L., de Matos Nogueira, E., Hemerly, A. S., and Domont, G. B. 2009. Proteome of Gluconacetobacter diazotrophicus co-cultivated with sugarcane plantlets. J. Proteomics 73:917931

Echave, P., Tamarit, J., Cabiscol, E., and Ros, J. 2003. Novel antioxidant role of alcohol dehydrogenase E from Escherichia coli. J. Biol. Chem. 278:30193-30198.

Falke, J. J., Bass, R. B., Butler, S. L., Chervitz, S. A., and Danielson, M A. 1997. The two-component signaling pathway of bacterial chemotaxis: A molecular view of signal transduction by receptors, kinases, and adaptation enzymes. Annu. Rev. Cell Dev. Biol. 13:457-512.

Feiler, H. S., Desprez, T., Santoni, V., Kronenberger, J., Caboche, M. and Traas, J. 1995. The higher plant Arabidopsis thaliana encodes a functional CDC48 homologue which is highly expressed in dividing and expanding cells. EMBO (Eur. Mol. Biol. Organ.) J. 14:56265637.

Fenselau, C. 2007. A review of quantitative methods for proteomic studies. J. Chromatogr. 855:14-20.

Ferguson, A. D., and Deisenhofer, J. 2002. TonB-dependent receptorsstructural perspectives. Biochim. Biophys. Acta 1565:318-332.

Fuentez-Ramirez, L. E., Jimenez-Salgado, T., Abarca-Ocampo, I. R., and Caballero-Mellado, J. 1993. Acetobacter diazotrophicus, an indoleacetic acid producing bacterium isolated from sugarcane cultivars of México. Plant Soil 154:145-150.

Fuentes-Ramirez, L. E., Bustillos-Cristales, R., Tapia-Hernandez, A., Jimenez-Salgado, T., Wang, E. T., Martinez-Romero, E., and CaballeroMellado, J. 2001. Novel nitrogen-fixing acetic acid bacteria, Gluconacetobacter johannae sp. nov. and Gluconacetobacter azotocaptans sp. nov., associated with coffee plants. Int. J. Syst. Evol. Microbiol. $51: 1305-1314$
Gibson, K. E., Kobayashi, H., and Walker, G. C. 2008. Molecular determinants of a symbiotic chronic infection. Annu. Rev. Genet. 42:413-441.

Hamer, R., Chen, P. Y., Armitage, J. P., Reinert, G., and Deane, C. M. 2010. Deciphering chemotaxis pathways using cross species comparisons. BMC Syst. Biol. 4:3.

Hardoim, P. R., van Overbeek, L. S., and Elsas, J. D. 2008. Properties of bacterial endophytes and their proposed role in plant growth. Trends Microbiol. 16:463-471.

Hebeler, R., Oeljeklaus, S., Reidegeld, K. A., Eisenacher, M., Stephan, C., Sitek, B., Stuhler, K., Meyer, H. E., Sturre, M. J., Dijkwel, P. P., and Warscheid, B. 2008. Study of early leaf senescence in Arabidopsis thaliana by quantitative proteomics using reciprocal ${ }^{14} \mathrm{~N} /{ }^{15} \mathrm{~N}$ labeling and difference gel electrophoresis. Mol. Cell. Proteomics 7:108-120.

Hendre, K. R., Iyer, R. S., Kotwain, M., Kluspe, S. S., and Mascarenhas, A. F. 1983. Rapid multiplication of sugarcane by tissue culture. Sugarcane 1:5-8.

Hendrickson, E. L., Xia, Q., Wang, T., Leigh, J. A., and Hackett, M. 2006. Comparison of spectral counting and metabolic stable isotope labeling for use with quantitative microbial proteomics. Analyst 131:1335-1341.

Hogslund, N., Radutoiu, S., Krusell, L., Voroshilova, V., Hannah, M. A., Goffard, N., Sanchez, D. H., Lippold, F., Ott, T., Sato, S., Tabata, S., Liboriussen, P., Lohmann, G. V., Schauser, L., Weiller, G. F., Udvardi, M. K., and Stougaard, J. 2009. Dissection of symbiosis and organ development by integrated transcriptome analysis of Lotus japonicus mutant and wild-type plants. PLoS One 4:e6556.

Hou, S., Yang, Y., and Zhou, J. M. 2009. The multilevel and dynamic interplay between plant and pathogen. Plant Signal. Behav. 4:283-293.

Huttlin, E. L., Hegeman, A. D., Harms, A. C., and Sussman, M. R. 2007. Comparison of full versus partial metabolic labeling for quantitative proteomics analysis in Arabidopsis thaliana. Mol. Cell. Proteomics 6:860-881.

Intorne, A. C., de Oliveira, M. V., Lima, M. L., da Silva, J. F., Olivares, F. L., and de Souza Filho, G. A. 2009. Identification and characterization of Gluconacetobacter diazotrophicus mutants defective in the solubilization of phosphorus and zinc. Arch. Microbiol. 191:477-483.

Jacobson, F. S., Morgan, R. W., Christman, M. F., and Ames, B. N. 1989 An alkyl hydroperoxide reductase from Salmonella typhimurium involved in the defense of DNA against oxidative damage. Purification and properties. J. Biol. Chem. 264:1488-1496.

James, E. K., Olivares, F. L., de Oliveira, A. L. M., dos Reis, F., da Silva, L. G., and Reis, V. M. 2001. Further observations on the interaction between sugar cane and Gluconacetobacter diazotrophicus under laboratory and greenhouse conditions. J. Exp. Bot. 52:747-760.

Jiao, H. J., Wang, S. Y., and Civerolo, E. L. 2008. Lipid composition of citrus leaves from plants resistant and susceptible to citrus bacterial canker. J. Phytopathol. 135:48-56.

Jimenez-Salgado, T., Fuentes-Ramirez, L. E., Tapia-Hernandez, A., Mascarua-Esparza, M. A., Martinez-Romero, E., and Caballero-Mellado, J. 1997. Coffea arabica L., a new host plant for Acetobacter diazotrophicus, and isolation of other nitrogen-fixing acetobacteria. Appl. Environ. Microbiol. 63:3676-3683.

Jung, K., and Altendorf, K. 2002. Towards an understanding of the molecular mechanisms of stimulus perception and signal transduction by the $\mathrm{KdpD} / \mathrm{KdpE}$ system of Escherichia coli. J. Mol. Microbiol. Biotechnol. 4:223-228.

Koebnik, R. 2005. TonB-dependent trans-envelope signalling: The exception or the rule? Trends Microbiol. 13:343-347.

Korndorfer, I. P., Dommel, M. K., and Skerra, A. 2004. Structure of the periplasmic chaperone Skp suggests functional similarity with cytosolic chaperones despite differing architecture. Nat. Struct. Mol. Biol. 11:1015-1020.

Krab, I. M., te Biesebeke, R., Bernardi, A., and Parmeggiani, A. 2001. Elongation factor Ts can act as a steric chaperone by increasing the solubility of nucleotide binding-impaired elongation factor-Tu. Biochemistry 40:8531-8535.

Kramer, R. 2009. Osmosensing and osmosignaling in Corynebacterium glutamicum. Amino Acids 37:487-497.

Laemmli, U. K. 1970. Cleavage of structural proteins during the assembly of the head of bacteriophage T4. Nature 227:680-685.

Lam, J., Chan, R., Lam, K., and Costerton, J. W. 1980. Production of mucoid microcolonies by Pseudomonas aeruginosa within infected lungs in cystic fibrosis. Infect. Immun. 28:546-556.

Lee, J., Kim, Y. B., and Kwon, M. 2007. Outer membrane protein H for protective immunity against Pasteurella multocida. J. Microbiol. 45:179-184.

Lee, S., Flores-Encarnacion, M., Contreras-Zentella, M., Garcia-Flores, L., Escamilla, J. E., and Kennedy, C. 2004. Indole-3-acetic acid biosynthesis is deficient in Gluconacetobacter diazotrophicus strains 
with mutations in cytochrome c biogenesis genes. J. Bacteriol. 186:5384-5391.

Lery, L. M., Coelho, A., von Kruger, W. M., Goncalves, M. S., Santos, M. F., Valente, R. H., Santos, E. O., Rocha, S. L., Perales, J., Domont, G. B., Teixeira, K. R., Bertalan, M., Ferreira, P. C., and Bisch, P. M. 2008a. Protein expression profile of Gluconacetobacter diazotrophicus PAL5, a sugarcane endophytic plant growth-promoting bacterium. Proteomics 8:1631-1644.

Lery, L. M., von Kruger, W. M., Viana, F. C., Teixeira, K. R., and Bisch, P. M. 2008b. A comparative proteomic analysis of Gluconacetobacter diazotrophicus PAL5 at exponential and stationary phases of cultures in the presence of high and low levels of inorganic nitrogen compound. Biochim. Biophys. Acta 1784:1578-1589.

Loganathan, P., Sunlta, R., Parlda, A. K., and Nair, S. 1999. Isolation and characterization of two genetically distant groups of Acetobacter diazotrophicus from a new host plant Eleusine coracana L. J. Appl. Microbiol. 87:167-172.

Long, H. H., Schmidt, D. D., and Baldwin, I. T. 2008. Native bacterial endophytes promote host growth in a species-specific manner; phytohormone manipulations do not result in common growth responses. PloS One 3:e2702.

Marenda, M., Brito, B., Callard, D., Genin, S., Barberis, P., Boucher, C., and Arlat, M. 1998. PrhA controls a novel regulatory pathway required for the specific induction of Ralstonia solanacearum hrp genes in the presence of plant cells. Mol. Microbiol. 27:437-453.

Markmann, K., and Parniske, M. 2009. Evolution of root endosymbiosis with bacteria: How novel are nodules? Trends Plant Sci. 14:77-86.

Martinez-Romero, E. 2009. Coevolution in Rhizobium-legume symbiosis? DNA Cell Biol. 28:361-370.

Masson-Boivin, C., Giraud, E., Perret, X., and Batut, J. 2009. Establishing nitrogen-fixing symbiosis with legumes: How many Rhizobium recipes? Trends Microbiol. 17:458-466.

Missiakas, D., Betton, J. M., and Raina, S. 1996. New components of protein folding in extracytoplasmic compartments of Escherichia coli SurA, FkpA and Skp/OmpH. Mol. Microbiol. 21:871-884.

Moscatiello, R., Alberghini, S., Squartini, A., Mariani, P., and Navazio, L. 2009. Evidence for calcium-mediated perception of plant symbiotic signals in aequorin-expressing Mesorhizobium loti. BMC Microbiol. 9:206.

Munoz-Rojas, J., and Caballero-Mellado, J. 2003. Population dynamics of Gluconacetobacter diazotrophicus in sugarcane cultivars and its effect on plant growth. Microb. Ecol. 46:454-464.

Muthukumarasamy, R., Revathi, G., Seshadri, S., and Lakshminarasimhan, C. 2002. Gluconacetobacter diazotrophicus (syn. Acetobacter diazotrophicus), a promising diazotrophic endophyte in tropics. Curr. Sci. 83:137-145.

Muthukumarasamy, R., Cleenwerck, I., Revathi, G., Vadivelu, M., Janssens, D., Hoste, B., Gum, K. U., Park, K. D., Son, C.Y., Sa, T., and Caballero-Mellado, J. 2005. Natural association of Gluconacetobacter diazotrophicus and diazotrophic Acetobacter peroxydans with wetland rice. Syst. Appl. Microbiol. 28:277-286.

Muthukumarasamy, R., Govindarajan, M., Vadivelu, M., and Revathi, G. 2006. N-fertilizer saving by the inoculation of Gluconacetobacter diazotrophicus and Herbaspirillum sp. in micropropagated sugarcane plants. Microbiol. Res. 161:238-245.

Nakamura, Y., Mizusawa, S., Court, D. L., and Tsugawa, A. 1986. Regulatory defects of a conditionally lethal nusAts mutant of Escherichia coli. Positive and negative modulator roles of NusA protein in vivo. J. Mol. Biol. 189:103-111.

Nguyen-nhu, N. T., and Knoops, B. 2002. Alkyl hydroperoxide reductase 1 protects Saccharomyces cerevisiae against metal ion toxicity and glutathione depletion. Toxicol. Lett. 135:219-228.

Nikaido, H. 2003. Molecular basis of bacterial outer membrane permeability revisited. Microbiol. Mol. Biol. Rev. 67:593-656.

Nogueira, E. M., Vinagre, F., Masuda, H. P., Vargas, C., Padua, V. L., Silva, F. R., Santos, R. V., Baldani, J. I., Ferreira, P. C. G., and Hemerly, A. S. 2001. Expression of sugarcane genes induced by inoculation with Gluconacetobacter diazotrophicus and Herbaspirillum rubrisubalbicans. Genet. Mol. Biol. 24:199-206.

Oecking, C., and Jaspert, N. 2009. Plant 14-3-3 proteins catch up with their mammalian orthologs. Curr. Opin. Plant Biol. 12:760-765.

Oeljeklaus, S., Meyer, H. E., and Warscheid, B. 2009. Advancements in plant proteomics using quantitative mass spectrometry. J. Proteomics 72:545-554

Ong, S. E., and Mann, M. 2005. Mass spectrometry-based proteomics turns quantitative. Nat. Chem. Biol. 1:252-262.

Ortiz-Castro, R., Contreras-Cornejo, H. A., Macias-Rodriguez, L., and Lopez-Bucio, J. 2009. The role of microbial signals in plant growth and development. Plant Signal. Behav. 4:701-712.

Pajerowska-Mukhtar, K., and Dong, X. 2009. A kiss of death-protea- some-mediated membrane fusion and programmed cell death in plant defense against bacterial infection. Genes Dev. 23:2449-2454.

Palmblad, M., Bindschedler, L. V., and Cramer, R. 2007. Quantitative proteomics using uniform (15)N-labeling, MASCOT, and the trans-proteomic pipeline. Proteomics 7:3462-3469.

Pao, S. S., Paulsen, I. T., and Saier, M. H., Jr. 1998. Major facilitator superfamily. Microbiol. Mol. Biol. Rev. 62:1-34.

Patel, S., and Latterich, M. 1998. The AAA team: Related ATPases with diverse functions. Trends Cell. Biol. 8:65-71.

Paul, A. L., Liu, L., McClung, S., Laughner, B., Chen, S., and Ferl, R. J. 2009. Comparative interactomics: Analysis of Arabidopsis 14-3-3 complexes reveals highly conserved 14-3-3 interactions between humans and plants. J. Proteome Res. 8:1913-1924.

Reinhold-Hurek, B., and Hurek, T. 1998. Life in grasses: Diazotrophic endophytes. Trends Microbiol. 6:139-144.

Reis, V. M., Olivares, F. L., and Döbereiner, J. 1994. Improved methodology for isolation of Acetobacter diazotrophicus and confirmation of its endophytic habitat. World J. Microbiol. Biotechnol. 10:401-405.

Reis, V. M., Olivares, F. L., de Oliveira, A. L. M., Junior, F. B. R., Baldani, I., and Döbereiner, J. 1999. Technical approaches to inoculate micropropagated sugar cane plants with Acetobacter diazotrophicus. Plant Soil 206:205-211.

Roberts, M. F. 2006. Inositol in bacteria and archaea. Subcell. Biochem. 39:103-133.

Roberts, M. R., Salinas, J., and Collinge, D. B. 2002. 14-3-3 proteins and the response to abiotic and biotic stress. Plant Mol. Biol. 50:10311039.

Ron, Z. E. 2006. Bacterial stress response. Prokaryotes 2:1012-1027.

Ryan, R. P., Germaine, K., Franks, A., Ryan, D. J., and Dowling, D. N. 2008. Bacterial endophytes: Recent developments and applications. FEMS (Fed. Eur. Microbiol. Soc.) Microbiol. Lett. 278:1-9.

Saravanan, V. S., Kalaiarasan, P., Madhaiyan, M., and Thangaraju, M. 2007. Solubilization of insoluble zinc compounds by Gluconacetobacter diazotrophicus and the detrimental action of zinc ion $(\mathrm{Zn} 2+)$ and zinc chelates on root knot nematode Meloidogyne incognita. Lett. Appl. Microbiol. 44:235-241.

Saravanan, V. S., Madhaiyan, M., Osborne, J., Thangaraju, M., and Sa, T. M. 2008. Ecological occurrence of Gluconacetobacter diazotrophicus and nitrogen-fixing Acetobacteraceae members: Their possible role in plant growth promotion. Microb. Ecol. 55:130-140.

Sevilla, M., Burris, R. H., Gunapala, N., and Kennedy, C. 2001. Comparison of benefit to sugarcane plant growth and $15 \mathrm{~N} 2$ incorporation following inoculation of sterile plants with Acetobacter diazotrophicus wild-type and Nif- mutants strains. Mol. Plant-Microbe Interact. 14:358-366.

Shigeoka, S., Ishikawa, T., Tamoi, M., Miyagawa, Y., Takeda, T., Yabuta, Y., and Yoshimura, K. 2002. Regulation and function of ascorbate peroxidase isoenzymes. J. Exp. Bot. 53:1305-1319.

Silva-Froufe, L.G. 2003. Aspectos estruturais da interação de bactéria diazotróficas endofíticas e cana de açúcar. Ph.D. thesis. Universidade Estadual do Norte Fluminense, Rio de Janeiro, Brazil.

Sleator, R. D., and Hill, C. 2002. Bacterial osmoadaptation: The role of osmolytes in bacterial stress and virulence. FEMS (Fed. Eur. Microbiol Soc.) Microbiol. Rev. 26:49-71.

Staskawicz, B. 2009. First insights into the genes that control plant-bacterial interactions. Mol. Plant Pathol. 10:719-720.

Stevenson, G., Andrianopoulos, K., Hobbs, M., and Reeves, P. R. 1996 Organization of the Escherichia coli K-12 gene cluster responsible for production of the extracellular polysaccharide colanic acid. J. Bacteriol. 178:4885-4893.

Takeuchi, A., Yamaguchi, M., and Uritani, I. 1981. ATP:citrate lyase from opomea potatoes root tissue infected with Ceratocystis fimbriata. Phytochemistry 20:1235-1239.

Tang, Y., Quail, M. A., Artymiuk, P. J., Guest, J. R., and Green, J. 2002 Escherichia coli aconitases and oxidative stress: Post-transcriptional regulation of sodA expression. Microbiology 148:1027-1037.

Tapia-Hernandez, A., Bustillos-Cristales, M. R., Jimenez-Salgado, T. Caballero-Mellado, J., and Fuentes-Ramirez, L. E. 2000. Natural endophytic occurrence of Acetobacter diazotrophicus in pineapple plants. Microb. Ecol. 39:49-55.

Urquiaga, S., Cruz, K. H. S., and Boddey, R. M. 1992. Contribution of nitrogen fixation to sugar cane: Nitrogen-15 and nitrogen-balance estimates. Soil Sci. Soc. Am. J. 56:105-114.

van der Lelie, D., Schwuchow, T., Schwidetzky, U., Wuertz, S., Baeyens, W., Mergeay, M., and Nies, D. H. 1997. Two-component regulatory system involved in transcriptional control of heavy-metal homoeostasis in Alcaligenes eutrophus. Mol. Microbiol. 23:493-503.

Veith, P. D., O’Brien-Simpson, N. M., Tan, Y., Djatmiko, D. C., Dashper, S. G., and Reynolds, E. C. 2009. Outer membrane proteome and antigens of Tannerella forsythia. J. Proteome Res. 8:4279-4292. 
Villeth, G. R., Reis, F. B., Jr., Tonietto, A., Huergo, L., de Souza, E. M., Pedrosa, F. O., Franco, O. L., and Mehta, A. 2009. Comparative proteome analysis of Xanthomonas campestris pv. campestris in the interaction with the susceptible and the resistant cultivars of Brassica oleracea. FEMS (Fed. Eur. Microbiol. Soc.) Microbiol. Lett. 298:260266.

Vinagre, F., Vargas, C., Schwarcz, K., Cavalcante, J., Nogueira, E. M., Baldani, J. I., Ferreira, P. C., and Hemerly, A. S. 2006. SHR5: A novel plant receptor kinase involved in plant- $\mathrm{N}_{2}$-fixing endophytic bacteria association. J. Exp. Bot. 57:559-569.

Vuilleumier, S. 1997. Bacterial glutathione S-transferases: What are they good for? J. Bacteriol. 179:1431-1441.

Winzer, K., Hardie, K. R., and Williams, P. 2002. Bacterial cell-to-cell communication: Sorry, can't talk now-gone to lunch! Curr. Opin. Microbiol. 5:216-222.
Yamanaka, K., and Inouye, M. 2001. Selective mRNA degradation by polynucleotide phosphorylase in cold shock adaptation in Escherichia coli. J. Bacteriol. 183:2808-2816.

Yan, W., and Chen, S. S. 2005. Mass spectrometry-based quantitative proteomic profiling. Brief. Funct. Genomics Proteomics 4:27-38.

Yu, A. Y., and Houry, W. A. 2007. ClpP: A distinctive family of cylindrical energy-dependent serine proteases. FEBS (Fed. Eur. Biochem. Soc.) Lett. 581:3749-3757.

Zuber, P. 2009. Management of oxidative stress in Bacillus. Annu. Rev. Microbiol. 63:575-597.

\section{AUTHOR-RECOMMENDED INTERNET RESOURCE}

Matrix Science website: www.matrixscience.com 